\title{
Boron Isotopes in the Ocean Floor Realm and the Mantle
}

\author{
Horst R. Marschall
}

\begin{abstract}
This chapter reviews the boron isotopic composition of the ocean floor, including pristine igneous oceanic crust such as mid-ocean ridge basalts and ocean island basalts and their implications for the B isotopic composition of the mantle. The chapter further discusses the B isotopic effects of assimilation of altered crustal materials in mantle-derived magmas. The systematics of seawater alteration on oceanic rocks are discussed, including sediments, igneous crust and serpentinization of ultramafic rocks and the respective marine hydrothermal vent fluids. The chapter concludes with a discussion of the secular evolution of the B isotopic composition of seawater.
\end{abstract}

\section{Keywords}

Boron isotopes - Oceanic crust - Alteration - Vent fluids - Mantle Seawater

H.R. Marschall ( $\square)$

Department of Geology and Geophysics, Woods Hole Oceanographic Institution, Woods Hole, MA 02543, USA

e-mail: hmarschall@whoi.edu; marschall@em. uni-frankfurt.de

H.R. Marschall

Institut Für Geowissenschaften, Goethe Universität Frankfurt, Altenhöferallee 1, 60438 Frankfurt Am Main, Germany

\subsection{Introduction}

The oceanic crust plays a key role in global geochemical cycles in several ways. Oceanic crust formation is the prime process of magma extraction from the mantle. Intense interaction of seawater with the lithosphere, particularly along the world's $65,000 \mathrm{~km}$ long mid-ocean ridge system, affects both seawater chemistry and the composition of the crustal rocks, as well as sections of the oceanic mantle (e.g., German and Lin 2004; Karson et al. 2015). The oceanic crust and part of the lithospheric mantle modified by 
interaction with the hydrosphere plus its sediment load are eventually subducted along the convergent plate margins, introducing chemical and isotopic heterogeneities into the mantle (e.g., Elliott et al. 1997; Jackson et al. 2007; Marschall and Schumacher 2012). Subduction of oceanic crust triggers the production of convergent-margin magmas that determines the composition of the newly produced continental crust today and probably throughout parts of Earth's history (e.g., Reymer and Schubert 1984; Dhuime et al. 2012). Ideal geochemical tracers that can be employed to detect and quantify these exchange processes should show large disparities in abundances among seawater, crustal rocks, sediments, altered rocks of the seafloor and the mantle, and should possess isotopic signatures that are strongly fractionated among the mantle, crust and hydrosphere.

Boron fulfils these criteria better than most other elements. It is a quintessentially crustal element with high concentrations in rocks of continental affinity and in rocks that interacted with the hydrosphere. Oceanic sediments, low-temperature altered oceanic basalts, and serpentinites show very high B abundances (10-200 $\mu \mathrm{g} / \mathrm{g})$, whereas the depleted mantle is characterised by very low B contents $(<0.1 \mu \mathrm{g} / \mathrm{g}$; Leeman and Sisson 1996). Fractionation of the two stable isotopes of boron $\left({ }^{10} \mathrm{~B}\right.$ and $\left.{ }^{11} \mathrm{~B}\right)$ at low temperatures is responsible for surface reservoirs that are enriched in boron with a ${ }^{11} \mathrm{~B}$-rich isotopic composition, and seawater is at the high end of the isotopic scale (Palmer and Swihart 1996).

Boron isotope analyses of pristine, unmetasomatised mantle samples has not been achieved yet, due to analytical limitations relative to the level of precision required for a geologically meaningful interpretation. However, fresh basaltic glasses erupted at mid-ocean ridges have been used to indirectly determine the boron elemental and isotopic composition of the convecting mantle, and ocean-island basalts have been investigated to identify possible recycled crustal materials in the mantle (Chaussidon and Jambon 1994; Chaussidon and Marty 1995; Marschall et al. 2017).
This chapter summarizes the boron isotope characteristics of the ocean-floor realm, including fresh and altered igneous crust and its connection to the mantle, as well as oceanic sediments and serpentinized ultramafic rocks exposed at the seafloor. Boron in hydrothermal vent fluids are reviewed for their bearing on seafloor alteration, and a brief summary of the secular change in the boron isotopic composition of seawater is given.

\subsection{The Oceanic Crust}

Approximately two thirds of the Earth are covered by large ocean basins submerged under, on average, a $4000 \mathrm{~m}$ deep layer of water. The oceanic crust is dominated by basalts, gabbros and exposed mantle rocks and has a limited age of approximately 0-200 Ma due to constant recycling (e.g., Müller et al. 2008). This contrasts with the elevated continents that comprise a diverse rock record spanning a very long history over billions of years (e.g., Dhuime et al. 2012). The oceanic crust is constantly formed at the mid-ocean ridges from where it drifts away, ages and is eventually subducted into the mantle at convergent plate margins. The processes operating at mid-ocean ridges are, therefore, central to the formation of the crust and key to understanding of its general structure and diverse types of crustal accretion process that have been distinguished (e.g., Reynolds et al. 1992; Dick et al. 2003; Escartín et al. 2008).

The textbook model for the structure of fast-spreading oceanic crust is the classic "Penrose model", named after the GSA 1972 Penrose Field Conference, where it was defined for the idealized structure of ophiolites (e.g., Dilek 2003). It consists of mantle and ultramafic cumulates at the bottom, overlain by successive layers of magmatic rocks, including gabbro, sheeted dikes and lava flows (sheets and pillows), and a top layer of siliceous and carbonaceous sediments. At slow-spreading ridges the spreading has a much larger tectonic component with disruption of the magmatic layers and exposure of serpentinized mantle at the seafloor (e.g., Dick et al. 2003). 
Boron abundances and isotopic compositions have been analysed for all the above-mentioned rock types and provide a picture of the boron isotopic inventory of the ocean floor. Hydrothermal activity, low-temperature alteration and weathering effectively mobilize boron and strongly influence the $\mathrm{B}$ isotopic composition of the affected rocks. These alteration processes have been studied through the investigation of altered rocks, hydrothermal vent fluids, and through laboratory experiments.

\subsection{Mid-Ocean Ridge Basalts}

Basaltic melts erupted along the global mid-ocean ridges are readily quenched to glass at contact with seawater, thus preserving the geochemical patterns of the melt that may otherwise be disturbed by crystallization and alteration processes in slower-cooled, crystalline rocks. Mid-ocean ridge basalt (MORB) glasses have, thus, been extensively used to decipher the composition of mantle-derived magmas and the composition of their sources, i.e. the upper, depleted, convecting mantle (e.g., Sun et al. 1979; Hofmann 1988; O’Neill and Jenner 2012).

The boron isotopic composition of unaltered MORB glasses has been investigated in several studies (Fig. 8.1) starting with Spivack and Edmond (1987). These authors analysed two samples from the East-Pacific Rise (EPR) resulting in a $\delta^{11} \mathrm{~B}$ of $-3.0 \pm 2.0 \%$. Ishikawa and Nakamura (1992) investigated a number of basaltic rocks from ODP Hole 504B (Galapagos Spreading Center) that showed variable degrees of hydrothermal alteration. They extrapolated the alteration trend back to the least altered sample and argued that $\delta^{11} \mathrm{~B}=+0.2 \%$ was representative of fresh MORB.

Chaussidon and Jambon (1994) analysed 17 MORB glasses from the EPR, the Mid-Atlantic Ridge (MAR) and the Red Sea and found $\delta^{11} \mathrm{~B}$ to range from -6.5 to $-1.2 \%$ with a mean of $-3.9 \pm 3.3 \%$. These authors observed a similar range of values in back-arc basin basalts and ocean-island basalts (OIB; see below). Based on

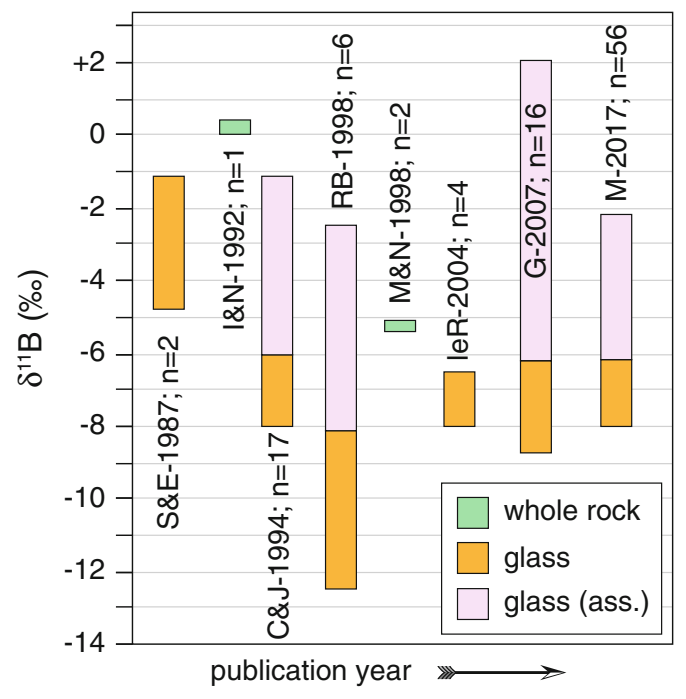

Fig. 8.1 Boron isotopic composition of unaltered, uncontaminated MORB as determined through analyses of MORB glass (yellow) and whole-rock samples (green). Elevated $\delta^{11} \mathrm{~B}$ values were found in MORB at various localities and were demonstrably related to assimilation of altered crust into the magmas beneath the ridge (pink ass. $=$ assimilation $)$. Sources are: S\&E-1987 = Spivack and Edmond (1987), I\&N-1992 = (Ishikawa and Nakamura 1992), C\&J-1994 = Chaussidon and Jambon (1994), RB-1998 = Roy-Barman et al. (1998), M\&N-1998 = Moriguti and Nakamura (1998), leR-2004 = le Roux et al. (2004), G-2007 = Gannoun et al. (2007), M-2017 = Marschall et al. (2017). 'n' refers to the number of unaltered MORB samples analyzed in each study

$\mathrm{K}_{2} \mathrm{O}, \mathrm{H}_{2} \mathrm{O}, \mathrm{MgO}$ and $\mathrm{B}$ content, as well as ${ }^{87} \mathrm{Sr} /{ }^{86} \mathrm{Sr}$ and ${ }^{2} \mathrm{H} /{ }^{1} \mathrm{H}$ ratios, they argued that the $\mathrm{B}$ isotope range observed in the oceanic basalts were not reflecting mantle source heterogeneities, but were due to the assimilation of seawater-altered materials by the magmas beneath the ridge prior to eruption. Chaussidon and Jambon (1994) argued that a value of $\delta^{11} \mathrm{~B}=-7.0 \pm 1.0 \%$ is most representative of the upper mantle.

Moriguti and Nakamura (1998) analyzed two rock samples from ODP Hole 648B (MAR) with $\delta^{11} \mathrm{~B}=-5.3 \pm 0.2 \%$, and le Roux et al. (2004) analyzed four glass samples from the EPR resulting in $\delta^{11} \mathrm{~B}=-7.3 \pm 0.8 \%$ o (Fig. 8.1).

Roy-Barman et al. (1998) investigated Os and $B$ isotopes of six MORB glasses from the MAR, 
Central Indian Ridge and the EPR. They showed that radiogenic Os is found in samples that also show isotopically heavy $\mathrm{B}$, most likely introduced by assimilation of altered crust. Their two MORB samples with ${ }^{187} \mathrm{Os} /{ }^{188} \mathrm{Os}<0.135$ have a $\delta^{11} \mathrm{~B}$ value of $-10.3 \pm 2.2 \%$, which they take as representative of the uncontaminated mantle, following Chaussidon and Marty (1995).

Gannoun et al. (2007) also completed a combined Os and B isotope study and analysed 16 MORB glasses from the EPR, MAR and the South-West Indian Ridge (SWIR). They too found a covariation of radiogenic Os with isotopically heavy $\mathrm{B}$, interpreted as a sign of assimilation of seawater-altered crust by the magma. This led to $\delta^{11} \mathrm{~B}$ values of as high as $+2.1 \%$. The glasses with the lowest ${ }^{187} \mathrm{Os} /{ }^{188} \mathrm{Os}(<0.135)$ have $\delta^{11} \mathrm{~B}$ values between -8.7 and $-6.2 \%$.

Marschall et al. (2017), the most recent and comprehensive study so far, investigated 56 MORB samples from the northern and southern MAR, the SWIR and from three sections of the EPR. Magma assimilation of altered crust (or seawater, or brines) was identified through elevated chlorine contents and $\mathrm{Cl} / \mathrm{K}$ ratio. A subset of 40 samples with $\mathrm{Cl} / \mathrm{K}<0.08$ was identified to represent uncontaminated MORB and was used to determine the mantle-derived boron isotopic compositions of the various ridge segments. The mean of the six different investigated ridge sections for samples with $\mathrm{Cl} / \mathrm{K}<0.08$ was $-7.1 \pm 0.9 \%$ o (2 standard deviation; Fig. 8.1). The majority of the low- $\mathrm{Cl} / \mathrm{K}$ samples show $\delta^{11} \mathrm{~B}$ values between -8.5 and $-6.0 \%$ with no resolvable differences among the various investigated ridge sections, and without any correlation with $\mathrm{Cl}, \mathrm{Li}$ or $\mathrm{B}$ contents (Marschall et al. 2017). Samples from diverse localities, such as the southern MAR, the SWIR and the various sections of the EPR all showed indistinguishable normal distributions around the mean value of $-7.1 \%$. Furthermore, no correlation was found between $\delta^{11} \mathrm{~B}$ and geochemical parameters that indicate the degree of depletion or enrichment of the mantle source of the MORB magmas, such as
$\mathrm{La} / \mathrm{Sm}, \mathrm{Ba} / \mathrm{TiO}_{2}$, or $\mathrm{Zr} / \mathrm{Y}$. Boron isotopes also did not show any systematic variation with radiogenic isotope ratios, such as those of $\mathrm{Sr}, \mathrm{Nd}$ or $\mathrm{Pb}$ (Marschall et al. 2017). Assimilation of altered crust, brines or seawater into the magmas at the ridge produced elevated $\mathrm{Cl}$ and $\mathrm{B}$ contents and $\delta^{11} \mathrm{~B}$ values of as high as $-2.2 \pm 1.7 \%$.

Shaw et al. (2012) presented H and B isotopes of 7 MORB glasses from the Manus basin with $\delta^{11} \mathrm{~B}$ value from $-10.8 \pm 1.0 \%$ to $-3.1 \pm 1.0 \%$ o that correlate positively with $\delta \mathrm{D}$. However, the Manus basin is very complex with possible influences of a plume, subducted slab, and a back-arc system, so that the isotope values of these samples are not representative of MORB produced at an open-ocean spreading center (Shaw et al. 2012).

Any comparison of all these $\delta^{11} \mathrm{~B}$ values published by a number of authors from different laboratories and determined by various analytical techniques need to take the analytical limitations into account. Well-established silicate reference materials for B isotope analysis only became available relatively recently (e.g., Jochum et al. 2006), and analytical protocols have been improved over the past two decades (e.g., Aggarwal et al. 2009; Foster et al. 2013, 2017; Marschall and Monteleone 2015). Discrepancies among the different studies from the 1980s and 1990s cited above and displayed in Fig. 8.1 at the level of 5\% or less are not likely to be significant, given the level of accuracy, inter-laboratory comparability and lack of internationally distributed $B$ isotope reference materials. Nonetheless, these studies established that the $\delta^{11} \mathrm{~B}$ value of fresh, uncontaminated MORB most likely had to be between approximately -12 and $0 \%$. Today, the best estimate for the $\delta^{11} \mathrm{~B}$ of uncontaminated MORB is $-7.1 \pm 0.9 \%$, and it is homogenous in boron isotopes on the level of current analytical precision and accuracy. It is further concluded that assimilation of seawater or seawater-altered materials produces elevated $\delta^{11} \mathrm{~B}$ values as observed in a number of MORB glass samples (Chaussidon and Jambon 1994; Marschall et al. 2017; Fig. 8.1). 


\subsection{Ocean Island Basalts}

Ocean island basalts (OIB) exhibit chemical and isotopic characteristics that distinguish them from the basalts typically erupted at mid-ocean ridges (Hofmann 1997, 2003). MORB represent the composition of the convecting upper mantle, and the excursions of the OIB from the MORB field require the existence of chemically, isotopically and possibly mineralogically distinct domains in the Earth's mantle (i.e., in the source of these OIB) that persist over hundreds of millions to billions of years (e.g., McKenzie and O'Nions 1983; Zindler and Hart 1986; Stracke et al. 2005).

The genesis of the enriched components in the mantle is a long-standing matter of debate, and various hypotheses have been put forward to explain their origin. One possibility is that radiogenic parent-daughter trace elements were fractionated in the mantle itself or by interaction of mantle and core (e.g., Vidal and Dosso 1978; Allègre et al. 1980; Menzies and Wass 1983; Halliday et al. 1990; Collerson et al. 2010). However, most studies favor subducted slabs as the origin of the enriched components in OIB (e.g., Chase 1981; Hofmann and White 1982; Weaver 1991; Jackson et al. 2007; Nebel et al. 2013).

The establishment of the connection between recycled surface materials and OIB and its quantification in terms of timescales and mass fractions is of foremost importance to the geosciences, as it would enable us to use the geochemical tracers in OIB to inform models on mantle convection and the long-term evolution of the crust-mantle system (c.f., van Keken et al. 2002).

The interpretation of radiogenic isotope data are complicated by the fact that isotope signatures naturally evolve differently with time depending on the parent/daughter abundance ratios in any particular mantle domain. This generally leaves a range of possible interpretations for the measured data with respect to residence time and mixing and convection mechanisms. The possibility of parent/daughter fractionation in the mantle adds ambiguity to radiogenic isotope signatures as tracers of recycled material.

An alternative tool to radiogenic isotopes are stable isotope ratios. These do not change over time and, hence, remove the uncertainty of time-dependent evolution models. Also, stable isotope fractionation is strong in crustal materials at the surface, but small or negligible in the hot mantle and in differentiating magmas. Stable isotope signatures of erupted lavas can, therefore, be interpreted to reflect mantle heterogeneities produced by recycled surface materials.

Boron stable isotopes in OIB have been employed by a number of studies in an attempt to identify recycled materials in their mantle sources. Analyses of B isotopes in OIB are less difficult and slightly more precise than B isotope analyses of MORB glasses, because many have higher $\mathrm{B}$ abundances by a factor of two to three (e.g., Ryan and Langmuir 1993). However, this does not apply to all OIB samples. In addition, two major obstacles have caused difficulties for the interpretation of the data, or demand cautiousness towards the interpretations proposed in the published studies discussed in more detail below:

(1) The boron isotopic composition of the upper mantle was not well defined in the past, and some studies have discussed the OIB data relative to a $\delta^{11} \mathrm{~B}$ value for the depleted upper mantle higher than $-7 \%$; such elevated $\delta^{11} \mathrm{~B}$ values in MORB have been identified as produced by shallow magma assimilation of seawater-altered materials and are not accepted as representative of the MORB mantle (see discussion above). An incorrect geochemical "baseline" for the mantle, i.e., for the mantle that does not contain recycled materials, inevitably leads to misinterpretations of data on possibly exotic mantle domains.

(2) Assimilation of even small amounts of hydrothermally altered materials by the OIB magmas during their ascent through the crust can influence their B isotopic composition, in which case the measured signal is no longer 
representative of the composition of the mantle source. This, on the other hand, makes B isotopes a sensitive indicator for crustal assimilation in basalts and they have been employed in OIB studies for this purpose.

The largest number of studies were completed on samples from Hawai'i and Iceland, with only a few published data from other ocean islands. Chaussidon and co-workers presented boron isotope data from Hawai'i and Iceland, as well as Galapagos, St. Helena, MacDonald seamount, and Afar (Fig. 8.2; Chaussidon and Jambon 1994; Chaussidon and Marty 1995; Gurenko and Chaussidon 1997; Roy-Barman et al. 1998). These studies consistently show positive correlations of $\delta^{11} \mathrm{~B}$ values and indicators of assimilation of low-temperature altered crust, such as increasing $\delta \mathrm{D}$ values or radiogenic Os. Decreasing $\mathrm{MgO}$ contents that correlate with increasing $\delta^{11} \mathrm{~B}$ indicate combined assimilation and fractional crystallization (Chaussidon and Jambon 1994). A second trend is observed in samples from subaerial volcanoes with $\delta^{18} \mathrm{O}$ values below that of uncontaminated mantle indicating assimilation of crust altered by high-temperature meteoric fluids: these samples show lower $\delta^{11} \mathrm{~B}$ values than MORB-source mantle, as low as $-14.6 \pm 3.0 \%$ (2SE) in samples from Afar (Fig. 8.2; Chaussidon and Marty 1995). The least contaminated OIB with the highest ${ }^{3} \mathrm{He} /{ }^{4} \mathrm{He}$ ratios are taken as representative of the OIB-source mantle with a relatively homogeneous $\delta^{11} \mathrm{~B}$ value for all investigated localities of $-10 \pm 2 \%$ o (Fig. 8.2; Chaussidon and Marty 1995). No boron isotope mantle heterogeneities are indicated in these studies and all excursions to high or low $\delta^{11} \mathrm{~B}$ values are demonstrated to be caused by assimilation of altered crust.

Hawai'i whole-rock isotope data from three different shield stages (Kilauea, Mauna Loa and Koolau) showed a very narrow range in $\delta^{11} \mathrm{~B}$ values from -5.4 to $-3.0 \%$ for 25 samples (Fig. 8.2; Tanaka and Nakamura 2005). The three stages show slightly different $\delta^{11} \mathrm{~B}$

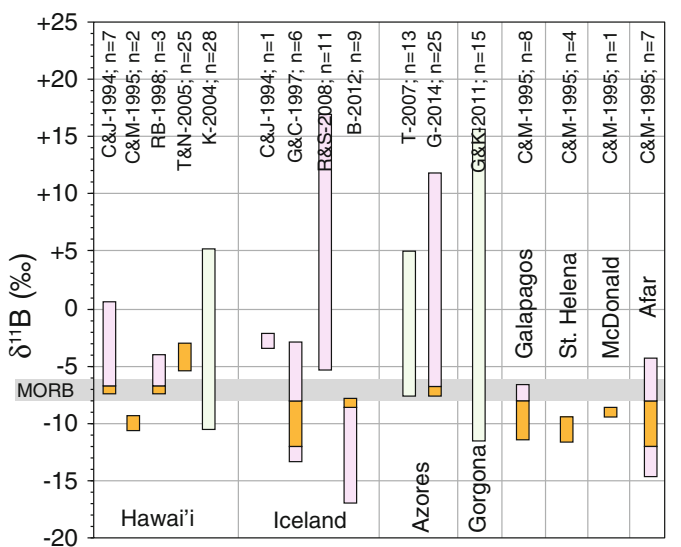

Fig. 8.2 Boron isotopic composition of unaltered OIB samples from various localities. Orange fields depict estimates of B isotopic composition of the OIB mantle source, whereas pink fields display samples with evidence for assimilation of hydrothermally altered crust. The green fields show samples that were interpreted to represent the heterogenous mantle sources of the OIB, but a reconsideration in the light of crustal assimilation has been published or is suggested here. Sources are: C\&J-1994 = Chaussidon and Jambon (1994), C\&M-1995 = Chaussidon and Marty (1995), RB-1998 = Roy-Barman et al. (1998), T\&N-2005 = Tanaka and Nakamura (2005), K-2004 = Kobayashi et al. (2004), R\&S-2008 = Rose-Koga and Sigmarsson (2008), B-2012 = Brounce et al. (2012), T-2007 = Turner et al. (2007), G-2014 = Genske et al. (2014), G\&K-2011 = Gurenko and Kamenetsky (2011). 'n' refers to the number of samples analyzed in each study, including analyses of matrix glass, melt inclusions, and whole-rock samples. MORB range from Marschall et al. (2017)

values of $-5.1 \pm 0.6 \%$ for Koolau, $-4.0 \pm$ $0.6 \%$ for Kilauea, and $-3.4 \pm 0.6 \%$ for Mauna Loa. Seawater-alteration and assimilation of altered crust were excluded as causes of these isotopic variations, because they do not correlate with B content nor with fractionation indicators (Tanaka and Nakamura 2005). Radiogenic isotopes show variations among these three Hawai'ian volcanoes, and the authors interpret the variation as a range between MORB-source mantle and deeply subducted sediments with a low $\delta^{11} \mathrm{~B}$ value. However, they take a value of $-3.3 \%$ for the unmodified MORB-source mantle and argue that values between approximately -4 and $-5.4 \%$, as observed in the Kilauea and Koolau lavas, would require a recycled sediment 
component. This model has to be reversed, however, if a $\delta^{11} \mathrm{~B}$ value for the MORB-source mantle of approximately $-7.1 \%$ is accepted, and a component with isotopically heavy B is required, instead, to explain the data for all three Hawai' ian volcanic centers.

In a very similar way, Kobayashi et al. (2004) interpreted data from melt inclusions in orthopyroxene and plagioclase from Hawai'i (28 analyses from 5 different samples, most of which were also analyzed by Tanaka and Nakamura 2005). Their data range from $-10.5 \pm 2.5 \%$ to $+5.2 \pm 2.6 \%$ o (Fig. 8.2). The authors use a $\delta^{11} \mathrm{~B}$ reference value of $-3 \pm 3 \%$ o for MORB-source mantle and interpret all observed values higher than that as due to assimilation of altered Hawai'ian crust into the magma (Kobayashi et al. 2004). Values lower than $-6 \%$ are taken as evidence for deeply recycled ancient subducted crust; however, there are no data that are significantly lower than the more recently suggested $\delta^{11} \mathrm{~B}$ value for the MORB-source mantle $(-7.1 \pm 0.9 \%$; Marschall et al. 2017), suggesting that all data may be explained by melts derived from mantle without an unusual B isotopic composition, and that the observed range may be due to various degrees of assimilation of altered crust. Kobayashi et al. (2004) also report a wide range of $\mathrm{Li}$ isotopes in the melt inclusions, but these would have to be revisited in the light of kinetic isotope fractionation during diffusion of $\mathrm{Li}$ in and out of the melt inclusions after entrapment.

A parallel story can be told about the Azores hot-spot lavas; initial boron isotope data from the Azores were interpreted to indicate deeply recycled oceanic crust based on an assumed MORB-source mantle value of $-4.6 \%$ and the idea that the lowest observed $\delta^{11} \mathrm{~B}$ values of $-7.6 \pm 1.0 \%$ would require a mantle component enriched in isotopically light $\mathrm{B}$ relative to the MORB source (Turner et al. 2007). A more recent study on the Azores (that involved some of the same authors) that included a larger number of samples from a larger number of islands in the archipelago also did not report any $\delta^{11} \mathrm{~B}$ lower than MORB source mantle (as defined by
Marschall et al. 2017), but a range of very high values of up to $+11.8 \%$ without any correlation to the observed range in radiogenic isotopes (Genske et al. 2014). The authors conclude that boron isotopes do not indicate mantle heterogeneities in the Azores, but that they are in general a very good tool to distinguish between different crustal assimilation processes in ocean-island basalts (Genske et al. 2014).

Gurenko and Kamenetsky (2011) found a range of $\delta^{11} \mathrm{~B}$ values from $-11.5 \pm 5.4 \%$ (2SD) to $+15.6 \pm 4.8 \%$ in olivine melt inclusions from Gorgona island komatiites, Columbia. The lowest $\delta^{11} \mathrm{~B}$ values are not significantly lower than MORB. The strongly elevated values that were observed were suggested to be due to hydrous metasomatism in the mantle source, rather than assimilation of altered crustal materials or brines by the ascending magma. This conclusion supports the model of komatiite formation by hydrous melting of the mantle rather than dry melting under extremely high temperatures (Gurenko and Kamenetsky 2011). The authors suggest that the mantle source was metasomatized by fluids derived from a subducting slab, which delivered isotopically heavy boron to the mantle source of the komatiites.

Boron isotope studies on various volcanic eruption products from Iceland revealed that assimilation of altered crust, as well as partial melting of altered crust may produce a large range of $\mathrm{B}$ isotopic compositions. Rose-Koga and Sigmarsson (2008) found the lowest $\delta^{11} \mathrm{~B}$ values (approximately $-5 \%$; Fig. 8.2) in basalts with mantle-like $\mathrm{O}$ isotopic composition. In contrast, strongly elevated $\delta^{11} \mathrm{~B}$ values (up to $+17 \%$ ) were found in rhyolites with low $\delta^{18} \mathrm{O}$ values and low ${ }^{230} \mathrm{Th} /{ }^{232} \mathrm{Th}$ ratios. The series of rocks are interpreted as mixing between mantle-derived basalts and crustal rhyolites derived from melting of hydrothermally-altered basalts (Rose-Koga and Sigmarsson 2008). Brounce et al. (2012) investigated plagioclase-hosted basaltic melt inclusions and basaltic matrix glass from the Laki Fissure eruption. They found $\delta^{11} \mathrm{~B}$ values in both groups of samples that range from mantle-like 
$(-7.8 \pm 4.2 \%$ o $)$ to enriched in the light isotope $\left(\delta^{11} \mathrm{~B}=-16.9 \pm 4.1 \%\right.$; Fig. 8.2). The latter were interpreted to be affected by assimilation of crustal materials into the magma that were altered by deeply-circulating meteoric water (Brounce et al. 2012). This interpretation is supported by volatile abundance analyses and by reports of low- $\delta^{11} \mathrm{~B}$ altered crust from the Icelandic Deep Drilling Project reported by Raffone et al. (2010).

In summary, the range of OIB samples investigated to date show a relatively wide range of $\delta^{11} \mathrm{~B}$ values. These excursions from the $\mathrm{B}$ isotopic composition of uncontaminated MORB is, to a large degree, generated by assimilation of crustal materials into the ascending magma. These crustal materials were altered by seawater or meteoric fluids and are enriched in isotopically heavy or light boron, respectively. Consequently, the identification of B isotopic heterogeneities in the mantle source of OIB is not easy, but may be achievable through combinations of various isotope and trace-element systems. Such uncontaminated mantle sources were suggested for Hawai'i with $\delta^{11} \mathrm{~B}$ values of approximately $-4 \pm 1 \%$ and for a range of other localities with values of $-10 \pm 2 \%$ (Fig. 8.2). It can, therefore, be concluded from all studies completed to date that the global $\delta^{11} \mathrm{~B}$ range of uncontaminated OIB is restricted to within four or five per mil of the $\delta^{11} \mathrm{~B}$ value of uncontaminated MORB, i.e., between -12 and $-3 \%$ (Fig. 8.2).

\subsection{The Mantle}

The boron isotopic composition of the mantle has not been analyzed directly. The first reason for this lack of data is that the abundances of $\mathrm{B}$ in unmetasomatized mantle rocks are too low to be analyzed with currently available methods to yield a precision and accuracy that would be geologically meaningful; the second reason is that it is very difficult to identify mantle samples that lack any metasomatic overprint, hydrothermal alteration, weathering or interaction with basaltic magmas. Any of these processes are prone to alter the abundance and isotopic composition of B in mantle samples.

As an alternative strategy, basalts and basaltic glasses have been used to unravel the B isotopic composition of the mantle, based on the idea that the boron isotope fractionation between rocks and silicate melt is negligible at magmatic temperatures (e.g., Chaussidon and Jambon 1994; Chaussidon and Marty 1995). Uncontaminated MORB and OIB should, therefore, faithfully record the unfractionated isotopic composition of their mantle sources. Marschall et al. (2017) discussed this connection between basalts and their mantle sources in more detail, based on experimentally determined boron partition coefficients between peridotitic and basaltic minerals and silicate melt, as well as estimated boron isotope fractionation factors. The latter are not well constraint by experiments and had to be extrapolated from experiments on other fluid, mineral and melt phases conducted at lower temperatures, and from a limited number of natural rocks (Marschall et al. 2017). Nevertheless, the authors concluded that uncontaminated mantle-derived basalts accurately reflect the $\delta^{11} \mathrm{~B}$ value of their mantle source within $\pm 0.30 \%$ and that crystal fractionation and magmatic differentiation do not change the $\mathrm{B}$ isotopic composition of magmas to a measurable degree, unless assimilation of altered crustal material occurs.

Heterogeneity of the global MORB-source mantle has been identified through radiogenic isotopes and trace elements, but no such variation is detectable for B isotopes at the current level of analytical precision $( \pm 0.9 \%$, 2 standard error; see discussion above; Marschall et al. 2017). The mantle domains sampled by OIB magmas may show a small variation with $\delta^{11} \mathrm{~B}$ values by up to $4 \%$ higher and up to 5\% lower than the MORB source mantle $(-10 \pm 2$ to $-4 \pm 1 \%$; see discussion above).

Marschall et al. (2017) argued that the $\delta^{11} \mathrm{~B}$ value of the depleted upper mantle is best represented by the global range of MORB with low $\mathrm{Cl} / \mathrm{K}$ that show a normal distribution around the mean of $-7.1 \pm 0.9 \%$ in their study (Fig. 8.3). Chaussidon and Jambon (1994) estimated a $\delta^{11} \mathrm{~B}$ 


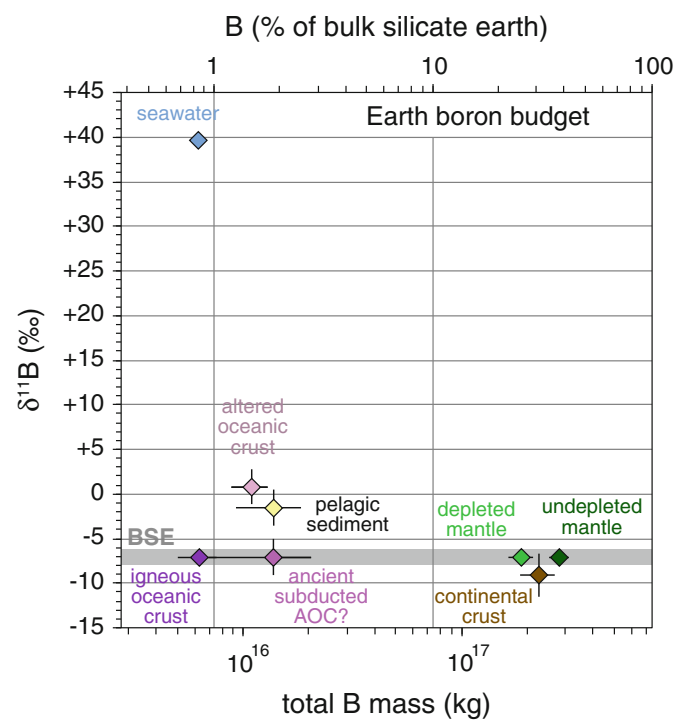

Fig. 8.3 Geochemical budget of B in Earth's major silicate reservoirs. Isotopic compositions versus the total mass of boron on the bottom $\mathrm{x}$-axis, and fraction of boron of the bulk silicate earth budget on the top x-axis. The bulk continental crust is estimated to be enriched in isotopically light B compared to the mantle. Ancient subducted AOC (altered oceanic crust) is estimated to be indistinguishable from the mantle in B isotopes (Figure from Marschall et al. 2017)

value of $-7 \pm 1 \%$ for the MORB-source mantle, but discussed the possibility that recycled materials derived from subducted altered oceanic crust could have enriched the upper mantle in isotopically heavy boron, and that the primitive mantle had a lower $\delta^{11} \mathrm{~B}$ than the one observed through uncontaminated MORB. However, Marschall et al. (2017) rejected this hypothesis based on the lack of variation in $\delta^{11} \mathrm{~B}$ among MORB samples from various global ridge sections, some of which show clear enriched or depleted geochemical signatures in radiogenic isotope space and trace elements. They argue that different portions of recycled materials into various parts of the global ridge system would express itself in a measurable boron isotopic variation, if the recycled material had sufficient amounts of exotic boron; but this has not been observed to date.

Chaussidon and Marty (1995) took the $\delta^{11} \mathrm{~B}$ value of $-10 \pm 2 \%$ o that they identified as the uncontaminated endmember of a range of OIB from various localities as representative of the primitive mantle. A subset of their OIB samples show high ${ }^{3} \mathrm{He} /{ }^{4} \mathrm{He}$ ratios indicating an undegassed (primitive) mantle source, and these samples are taken as representative of the primitive mantle $\delta^{11} \mathrm{~B}$ value. However, it should be noted that the boron isotopic composition of OIB samples are prone to contamination (as discussed above), and that the primitive mantle value estimated by Chaussidon and Marty (1995) overlaps within error with the MORB-source mantle value estimated by Marschall et al. (2017). Furthermore, interlaboratory comparison and accuracy limitations among the various studies that have been conducted over a time span of several decades additionally blur the picture. Future research should focus on the least contaminated OIB samples and unravel the variation in the OIB mantle sources and a possible difference between the OIB and MORB-source mantle.

In contrast to the complications seen in MORB and OIB, clear variation and mostly strongly elevated $\delta^{11} \mathrm{~B}$ values exist in basalts erupted along subduction zones, and these are interpreted to represent addition of isotopically heavy boron to the mantle source of arc magmas (de Hoog and Savov 2017). Supra-subduction mantle, therefore, experiences the addition of isotopically distinct boron ultimately derived from seawater (de Hoog and Savov 2017).

\subsection{Hydrothermal Alteration and Weathering}

Unaltered mafic igneous and ultramafic rocks show low concentrations of boron combined with a relatively well-constrained boron isotopic composition, as discussed above for MORB, OIB and the mantle. Modern seawater, in contrast, shows higher boron concentrations than most unaltered basalt, gabbro, and peridotite samples (4.5 $\mu \mathrm{g} / \mathrm{g}$; Uppstroem 1974; Spivack and Edmond 1987), and its isotopic composition is strongly enriched in the heavy isotope $(+39.61 \pm 0.04 \%$; Table 8.1; Fig. 8.3; Spivack and Edmond 1987; Foster et al. 2010). 
Fluid-rock interaction in rocks of the oceanic crust is frequently identified and quantified using $\mathrm{O}$ and $\mathrm{Sr}$ isotopes (e.g., Alt 1995; Hart et al. 1999; Bach et al. 2001), and these tracers work very reliably in hydrothermal systems with relatively high fluid-rock ratios. The trace element $\mathrm{B}$ with its distinct isotopic seawater-mantle dichotomy is an ideal tracer for alteration processes at the seafloor, and it can be used to detect even the smallest influence of seawater or seawater-derived fluids on rocks and magmas (e.g., Chaussidon and Jambon 1994; Marschall 2017). Low- and high-temperature altered oceanic crust and serpentinized mantle rocks show significant alterations in their B contents and B isotopic compositions.

\subsubsection{Alteration of the Igneous Crust}

The B isotopic composition of hydrothermally overprinted and weathered rocks is variable and depends on temperature, fluid/rock ratio, $\mathrm{pH}$ of the fluid and the type of secondary minerals (in particular their crystallographic coordination of B). Weathering of basalt at the seafloor produces smectite with tetrahedrally coordinated $\mathrm{B}$ in contact to seawater $\left(\delta^{11} \mathrm{~B}=+39.6 \%\right.$, 80\% $\mathrm{B}$ in trigonal coordination). Boron isotope fractionation under these conditions is large and weathered basalts are expected to display low $\delta^{11} \mathrm{~B}$ values relative to seawater. Experimentally and theoretically determined $\mathrm{B}$ isotope fractionation is approximately $30-35 \%$ for temperatures of the seafloor $\left(\sim 0{ }^{\circ} \mathrm{C}\right)$ (Schwarcz et al. 1969; Palmer et al. 1987; Kowalski and Wunder 2017), and a $\delta^{11} \mathrm{~B}$ value of +5 to $+10 \%$ could be expected for alteration in contact to seawater. Spivack and Edmond (1987) determined a B isotope fractionation of $32 \%$ between seawater and alteration products of basalt, with a $\delta^{11} \mathrm{~B}$ value of $+8 \%$ for the alteration products. Theoretical and experimental work further predicts that alteration at a temperature of $100{ }^{\circ} \mathrm{C}$ would result in a $\delta^{11} \mathrm{~B}$ value of $+18 \%$ in the secondary minerals (see Kowalski and Wunder 2017).
Low-temperature alteration $\left(<150{ }^{\circ} \mathrm{C}\right)$ and seafloor weathering generally lead to a strong enrichment of boron in the alteration products (mainly in clays) with abundances of up to $140 \mu \mathrm{g} / \mathrm{g}$ (Thompson and Melson 1970; Donnelly et al. 1979; Spivack and Edmond 1987). Weathering and low- $T$ alteration by seawater leads to a $\mathrm{B}$ isotopic signature that is enriched in the heavy isotope $\left({ }^{11} \mathrm{~B}\right)$ compared to fresh MORB, and $\delta^{11} \mathrm{~B}$ values that range from -4 to as high as $+25 \%$ have been found in low-temperature altered MORB (Table 8.1; Fig. 8.4; Spivack and Edmond 1987; Ishikawa and Nakamura 1992; Smith et al. 1995). Nonetheless, the majority of data for low-temperature altered MORB shows $\delta^{11} \mathrm{~B}$ values varying between 0 and $+5 \%$, whereas higher $\delta^{11} \mathrm{~B}$ values are found in basalts and gabbros that were altered at higher temperatures (Fig. 8.4). The B isotopic composition of these rocks show a relatively large scatter as a function of boron concentrations; nevertheless, their is a tendency towards higher $\delta^{11} \mathrm{~B}$ in low-B samples in altered gabbros and basalts (Fig. 8.4a), whereas the ultramafic rocks are invariably enriched in the heavy isotope at high B concentrations (Fig. 8.4 b). There is a negative correlation (albeit weak) between $\delta^{11} \mathrm{~B}$ and $\delta^{18} \mathrm{O}$ for the combined data from altered ophiolite rocks and MORB (Fig. 8.4c). This demonstrates that high alteration temperatures in basalts and gabbros lead to a moderate enrichment of isotopically very heavy boron or, in some cases, a loss of isotopically light boron, whereas low-temperature alteration leads to a strong enrichment of boron with a moderately elevated $\delta^{11} \mathrm{~B}$ value. This is consistent with a decrease of fluid-mineral boron isotope fractionation as temperature increases, and with a preferential up-take of B by clay minerals at very low temperatures, contrasted with leaching of boron from the rocks at high temperatures.

The evaluation of the imprint of high- $T$ alteration is complicated by the fact that rocks that experienced high- $T$ alteration subsequently cooled prior to sampling and are likely to also record lower- $T$ alteration. Whole-rock analyses of high- $T$ altered rocks are, therefore, prone to 
Table 8.1 Compilation of published boron data for different rocks, fluids, and reservoirs

\begin{tabular}{|c|c|c|c|}
\hline Material & $\delta^{11} \mathrm{~B}(\%)$ & {$[\mathrm{B}](\mu \mathrm{g} / \mathrm{g})$} & References \\
\hline \multirow[t]{3}{*}{ MORB-source mantle } & $-7 \pm 1$ & 0.065 & Chaussidon and Jambon (1994) \\
\hline & $-10 \pm 2$ & $\begin{array}{l}0.010- \\
0.015\end{array}$ & Chaussidon and Marty (1995) \\
\hline & $-7.1 \pm 0.9$ & 0.060 & Marschall et al. (2017) \\
\hline \multirow[t]{3}{*}{ Primitive mantle } & $-7 \pm 1$ & $0.25 \pm 0.10$ & Chaussidon and Jambon (1994) \\
\hline & $-10 \pm 2$ & 0.090 & Chaussidon and Marty (1995) \\
\hline & $-7.1 \pm 0.9$ & 0.173 & Marschall et al. (2017) \\
\hline \multirow[t]{2}{*}{ Continental crust } & $-10 \pm 3$ & 10 & Chaussidon and Albarède (1992) \\
\hline & $-9.4 \pm 0.4$ & 11 & Marschall et al. (2017) \\
\hline Upper continental crust & -8.8 & 43 & Kasemann et al. (2000) \\
\hline \multirow[t]{2}{*}{ Modern seawater } & $+39.5 \pm 0.3$ & 4.5 & Spivack and Edmond (1987) \\
\hline & $+39.61 \pm 0.04$ & n.d. & Foster et al. (2010) \\
\hline \multicolumn{4}{|l|}{ Vent fluids } \\
\hline \multirow{4}{*}{$\begin{array}{l}\text { Mid-ocean ridge, basalt-hosted } \\
\text { (sediment-starved) }\end{array}$} & +30.0 to +36.8 & $4.9-5.9$ & Spivack and Edmond (1987) \\
\hline & +26.7 to +36.8 & $3.8-6.1$ & Palmer (1991) \\
\hline & +24.3 to +26.0 & $4.5-5.1$ & James et al. (1995) \\
\hline & +28.5 to +35.2 & $5.4-6.9$ & You et al. (1994) \\
\hline \multirow[t]{2}{*}{ Back arc basin (sediment starved) } & +22.5 to +29.8 & $8.1-8.8$ & Palmer (1991) \\
\hline & +17.8 to +38.0 & $4.4-11$ & Yamaoka et al. (2015a) \\
\hline \multirow[t]{2}{*}{ Mid-ocean ridge (sediment hosted) } & +10.1 to +23.2 & $17-23$ & Palmer (1991) \\
\hline & -2.2 to +22.6 & $2.9-105$ & James et al. (1999) \\
\hline \multirow[t]{2}{*}{ Back arc basin (sediment hosted) } & -1.0 to +9.2 & $22-37$ & You et al. (1994) \\
\hline & +2.3 to +19.1 & $7.4-51$ & Yamaoka et al. (2015a) \\
\hline \multirow{2}{*}{$\begin{array}{l}\text { Ultramafic hosted } \\
\text { Marine evaporite setting }\end{array}$} & +25 to +30 & $0.3-3.6$ & e.g. Foustoukos et al. (2008) \\
\hline & +29.7 to +39.0 & $6.8-8.8$ & Palmer (1991) \\
\hline \multicolumn{4}{|l|}{ Altered MORB } \\
\hline \multirow[t]{2}{*}{$<150{ }^{\circ} \mathrm{C}^{\mathrm{a}}$} & +0.1 to +9.2 & $8.9-69$ & Spivack and Edmond (1987) \\
\hline & -4.3 to +24.9 & $1.1-104$ & Smith et al. (1995) \\
\hline$>150{ }^{\circ} \mathrm{C}^{\mathrm{a}}$ & -0.1 to +1.0 & $0.17-0.52$ & Ishikawa and Nakamura (1992) \\
\hline \multirow[t]{5}{*}{ Serpentinite } & +8.3 to +12.6 & $50-81$ & Spivack and Edmond (1987) \\
\hline & +7.0 to +9.9 & n.d. & Lécuyer et al. (2002) \\
\hline & +11.4 to +16.3 & $34-91$ & Boschi et al. (2008) \\
\hline & +29.6 to +40.7 & $10-65$ & Vils et al. (2009) \\
\hline & +9.3 to +19.6 & $19-36$ & Harvey et al. (2014) \\
\hline \multicolumn{4}{|l|}{ Ophiolites } \\
\hline Oman pillows $\left(<60{ }^{\circ} \mathrm{C}^{\mathrm{a}}\right)$ & -1.1 to +11.9 & $1.4-29.1$ & Yamaoka et al. (2012) \\
\hline Troodos pillows & +0.2 to +15.6 & $3.8-207$ & Yamaoka et al. (2015b) \\
\hline Oman sheeted dikes $\left(<200-350{ }^{\circ} \mathrm{C}^{\mathrm{a}}\right)$ & +1.1 to +17.5 & $1.5-11.6$ & Yamaoka et al. (2012) \\
\hline Oman sheeted dikes & -1.6 to +16.9 & $5.0-11.1$ & Smith et al. (1995) \\
\hline
\end{tabular}


Table 8.1 (continued)

\begin{tabular}{|c|c|c|c|}
\hline Material & $\delta^{11} \mathrm{~B}(\%)$ & {$[\mathrm{B}](\mu \mathrm{g} / \mathrm{g})$} & References \\
\hline Troodos sheeted dikes & +3.3 to +10.6 & $0.6-18$ & Yamaoka et al. (2015b) \\
\hline $\begin{array}{l}\text { Troodos sheeted dikes } \\
\left(\delta^{18} \mathrm{O}>+6 \% \text { ) }\right.\end{array}$ & -0.9 to +7.2 & $3.1-8.1$ & Smith et al. (1995) \\
\hline Troodos sheeted dikes $\left(\delta^{18} \mathrm{O} \leq+5 \%\right)$ & -0.1 to +7.8 & $2.4-3.4$ & Smith et al. (1995) \\
\hline Oman upper gabbros $\left(350-450{ }^{\circ} \mathrm{C}^{\mathrm{a}}\right)$ & +8.3 to +18.6 & $1.6-5.0$ & Yamaoka et al. (2012) \\
\hline Oman lower gabbros $\left(>450{ }^{\circ} \mathrm{C}^{\mathrm{a}}\right)$ & +7.3 to +17.7 & $0.25-3.8$ & Yamaoka et al. (2012) \\
\hline Troodos gabbros & -1.7 to +18.5 & $0.3-8.4$ & Yamaoka et al. (2015b) \\
\hline Oman serpentinites & -5.7 to +10.0 & n.d. & Yamaoka et al. (2012) \\
\hline \multicolumn{4}{|l|}{ Marine sediments } \\
\hline \multirow[t]{3}{*}{ Carbonate sediment } & -5.0 to +23.0 & $0.3-7$ & Spivack and You (1997) \\
\hline & +8.9 to +26.2 & $10-17$ & Vengosh et al. (1991) \\
\hline & +4.8 to +10.5 & $13-26$ & Ishikawa and Nakamura (1993) \\
\hline Calcareous sediment & +18.4 to +18.9 & n.d. & Lécuyer et al. (2002) \\
\hline \multirow[t]{3}{*}{ Pelagic clay } & -4.3 to +2.8 & $64-157$ & Spivack et al. (1987) \\
\hline & -6.6 to -1.8 & $96-132$ & Ishikawa and Nakamura (1993) \\
\hline & -13.1 to +4.0 & $101-163$ & Tonarini et al. (2011) \\
\hline Chert & -9.3 to +7.7 & 49-97 & Kolodny and Chaussidon (2004) \\
\hline \multirow[t]{2}{*}{ Siliceous ooze and biogenic silica } & -3.8 to +4.5 & $55-77$ & Ishikawa and Nakamura (1993) \\
\hline & -11.8 to +5.4 & $86-148$ & Tonarini et al. (2011) \\
\hline Turbidite & -6 to -2 & $75-105$ & You et al. (1995) \\
\hline Borates & +18.2 to +31.7 & $\begin{array}{l}\text { several wt } \\
\%\end{array}$ & Swihart and Moore (1986) \\
\hline \multirow[t]{4}{*}{ Marine sediment pore fluids } & +27.8 to +37.8 & $3.2-21$ & James and Palmer (2000), ODP 1037 \\
\hline & +34.6 to +43.9 & $3.6-6.0$ & Kopf et al. (2000), ODP 1039B \\
\hline & +34.4 to +40.5 & $0.1-5$ & Spivack and You (1997), ODP 851 \\
\hline & +35 to +49 & $4-12$ & You et al. (1995), ODP 808 \\
\hline \multicolumn{4}{|l|}{ Biogenic carbonate } \\
\hline \multirow[t]{7}{*}{ Corals (aragonite) } & +23.0 to +24.7 & $50-68$ & Hemming and Hanson (1992) \\
\hline & +26.7 to +31.9 & $51-80$ & Vengosh et al. (1991) \\
\hline & +23.3 to +27.0 & $49-58$ & Gaillardet and Allegre (1995) \\
\hline & +23.9 to +26.2 & $46-54$ & Hemming et al. (1998) \\
\hline & +23.1 to +26.1 & n.d. & Lécuyer et al. (2002) \\
\hline & +27.9 to +38.5 & $53-114$ & Blamart et al. (2007) \\
\hline & +20.9 to +29.3 & $28-56$ & Allison et al. (2010) \\
\hline Ancient corals & +23.6 to +27.3 & $39-52$ & Gaillardet and Allegre (1995) \\
\hline Bivalves, algae and ooids (aragonite) & $\begin{array}{l}+21.2 \text { to }+22.2 \\
+20.1 \text { to }+25.3\end{array}$ & $\begin{array}{l}14-28 \\
11-15\end{array}$ & $\begin{array}{l}\text { Hemming and Hanson (1992), Vengosh } \\
\text { et al. (1991) }\end{array}$ \\
\hline Gastropoda (aragonite) & +19.8 to +31.5 & $2-3$ & Vengosh et al. (1991) \\
\hline \multirow[t]{2}{*}{ Foraminifera (calcite) } & +4.9 to +32.2 & $9-54$ & Vengosh et al. (1991) \\
\hline & +21.6 to +25.9 & n.d. & Pearson and Palmer (2000) \\
\hline
\end{tabular}


Table 8.1 (continued)

\begin{tabular}{l|l|l|l}
\hline Material & $\delta^{11} \mathrm{~B}(\%)$ & {$[\mathrm{B}](\mu \mathrm{g} / \mathrm{g})$} & References \\
\hline & +12.0 to +16.8 & $3-26$ & Rae et al. (2011) \\
\cline { 2 - 4 } & +19.6 to +20.7 & $8-13$ & Foster (2008) \\
\hline Brachiopoda, gastropoda (calcite) & +15.0 to +19.7 & n.d. & Lécuyer et al. (2002) \\
\cline { 2 - 4 } & +18.5 to 20.8 & $19-26$ & Hemming and Hanson (1992) \\
\hline Algae, echinoids (high-Mg calcite) & +22.3 to 23.0 & $44-55$ & Hemming and Hanson (1992) \\
\hline Forearc & +22.1 to 27.9 & $65 \pm 5$ & Fietzke et al. (2015) \\
\hline Serpentinite seamount & & & \\
\hline Mud volcanoes & +5.4 to +25.3 & $6.6-126$ & Benton et al. (2001) \\
\hline Trench fluids & -7.7 to +39.5 & $2-870$ & Kopf and Deyhle (2002) \\
\hline
\end{tabular}

${ }^{\mathrm{a}}$ The temperatures refer to estimates for the conditions of hydrothermal alteration of these samples at the seafloor. $n . d$. not determined

record a contaminated signal. In the case of boron this contamination can be severe, due to the large difference in concentrations between high- and low- $T$ alteration products, respectively. No boron concentration or boron isotope analyses of mineral separates or in situ analyses of minerals from high-temperature altered oceanic crust have been published. Whole-rock analyses are available for samples from two ODP drill cores and from ophiolites (Oman and Troodos; Fig. 8.4).

High-temperature altered samples from ODP Hole 504B (Costa Rica Rift) show low B concentrations $(0.17-0.52 \mu \mathrm{g} / \mathrm{g})$ and $\delta^{11} \mathrm{~B}$ values close to 0\%o (Ishikawa and Nakamura 1992). High-temperature altered samples from Hole 735B (Atlantis Bank, Indian Ocean) show higher abundances of $\mathrm{B}(1.1-7.1 \mu \mathrm{g} / \mathrm{g})$ and a wide range of mostly high $\delta^{11} \mathrm{~B}$ values between -4.3 and +24.9\%o (Smith et al. 1995; Hart et al. 1999; see Fig. 8.4) High-temperature altered Layer-3 samples from the Troodos and Oman ophiolites range from slightly depleted to strongly enriched in boron $(0.25-11.6 \mu \mathrm{g} / \mathrm{g}$; Table 8.1$)$ with respect to fresh MORB, and they show significantly elevated $\delta^{11} \mathrm{~B}$ values of -1.7 to $+18.6 \%$, but mostly between +8 and $+18 \%$ (Fig. 8.4 ; Smith et al. 1995; Yamaoka et al. 2012, 2015b).

The interpretation of the ophiolite data is, however, complicated by the tectonic setting in which the exposed crust was formed and where the hydrothermal alteration took place, i.e., a supra-subduction zone rather than a mid-ocean ridge (e.g., Searle and Cox 1999; Fonseca et al. 2017). For example, glass orbicules from the upper pillow lava section in the Troodos ophiolite show geochemical evidence for the contribution of sediment melts and subduction-zone fluids to the depleted-mantle derived magmas that formed these lavas, as demonstrated by Fonseca et al. (2017). These authors found that $\delta^{11} \mathrm{~B}$ in these glass orbicules range from low values $(-8.2 \pm 0.5 \%$ ) indistinguishable from the depleted mantle to strongly elevated values $(+5.9 \pm 1.1 \%)$, with a negative correlation of $\delta^{11} \mathrm{~B}$ and $\mathrm{B}$ concentrations $(\approx 3-10 \mu \mathrm{g} / \mathrm{g})$. These boron isotopic signatures were observed in fresh glass and are not the result of seafloor alteration. Instead, they are interpreted as contributions to the Troodos ophiolite magmas in a subduction setting, in which isotopically heavy B was likely contributed from the slab (Fonseca et al. 2017; see also Chap. 9 of this volume). Further 
(a)

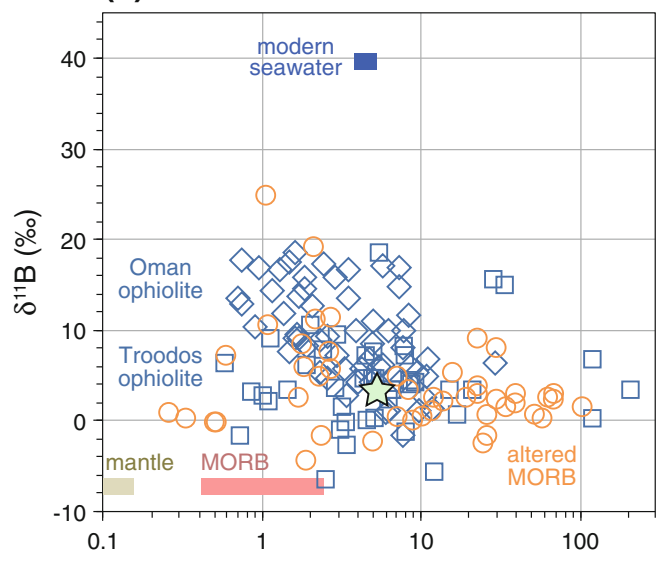

[B] $(\mu \mathrm{g} / \mathrm{g})$

(c)

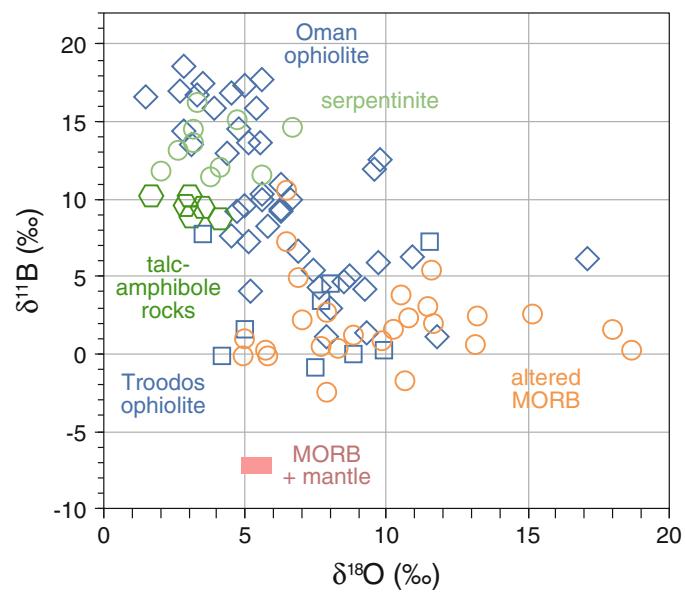

Fig. 8.4 a Boron isotopic composition versus B concentration of altered mafic rocks sampled from the ocean floor (orange circles) and from ophiolites (blue squares and diamonds). The altered-oceanic crust composite for ODP Hole 735B of Smith et al. (1995) is shown by the green star. b Boron isotopic composition versus B

complication of the interpretation of ophiolite data arises from the possibility of post-obduction low-temperature hydrous alteration involving meteoric fluids (e.g., Chavagnac et al. 2013).

\subsubsection{Serpentinization}

Serpentinites formed at the ocean floor by hydration of peridotites are strongly enriched in boron with concentrations between 10 and (b)

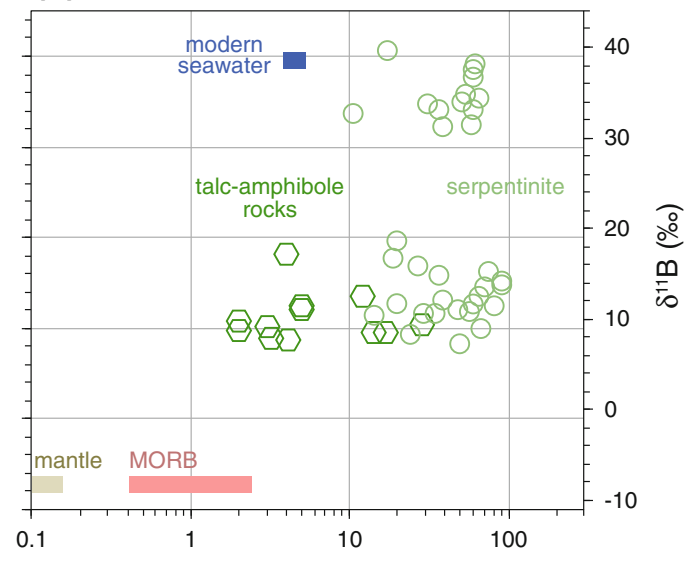

[B] $(\mu \mathrm{g} / \mathrm{g})$ concentration of serpentinites (green circles) and talc-amphibole-rich metasomatic rocks recovered from the ocean floor (green hexagons). c Boron isotopic composition versus oxygen isotopic composition for a subset of the samples displayed in (a) and (b) for which data were available. See Table 8.1 for data sources

$91 \mu \mathrm{g} / \mathrm{g}$ (Fig. 8.4; Table 8.1). Most samples display $\delta^{11} \mathrm{~B}$ values between +7.0 and $+19.9 \%$ (Fig. 8.4; Table 8.1; Spivack and Edmond 1987; Lécuyer et al. 2002; Boschi et al. 2008; Harvey et al. 2014). Exceptionally high $\delta^{11} \mathrm{~B}$ values were found in serpentinites from ODP Leg 209 (Mid-Atlantic Ridge) of approximately +30 to +41\%o (Fig. 8.4; Table 8.1; Vils et al. 2009). The latter were explained by serpentinization by seawater-derived fluids that were processed 
through interaction with mantle rocks prior to serpentinization of the investigated samples, leading to a strong enrichment of isotopically heavy boron. Vils et al. (2009) predict evolved serpentinization fluids with $\delta^{11} \mathrm{~B}$ values between +50 and $+60 \%$, which have yet to be discovered. Lower $\delta^{11} \mathrm{~B}$ values between -6 and $+10 \%$ were reported for serpentinites from the Oman ophiolite (Table 8.1; Lécuyer et al. 2002).

Serpentinized ultramafic rocks, therefore, have the ability to incorporate very high concentrations of B that is enriched or strongly enriched in the heavy isotope. This enrichment also occurs at high alteration temperatures, conditions at which mafic rocks tend to show loss of boron or only very minor enrichment (Fig. 8.4).

Metasomatic rocks produced by the interaction of serpentinites with silica-rich fluids derived from gabbroic intrusions have been investigated along with coexisting serpentinites (Boschi et al. 2008; Harvey et al. 2014). These rocks are rich in talc, as well as tremolite or chlorite, the formation of which postdates serpentinization (Boschi et al. 2008; Harvey et al. 2014). This steatitization process led to boron loss from the samples compared to the serpentinite precursor with concentrations ranging from 2.0 to $28.7 \mu \mathrm{g} / \mathrm{g}$ (Fig. 8.4). This is accompanied by a small isotopic shift to lower $\delta^{11} \mathrm{~B}$ values between +8.8 and $+13.5 \%$ for all but one sample (Boschi et al. 2008; Harvey et al. 2014).

\subsubsection{Hydrothermal Vent Fluids}

Boron concentrations and $\mathrm{B}$ isotope ratios have been reported for hydrothermal vent fluids from sediment-starved systems at the Mid-Atlantic Ridge (MARK, $23^{\circ} \mathrm{N}$; TAG, $26^{\circ} \mathrm{N}$; Broken Spur, $29^{\circ} \mathrm{N}$ ), the Juan de Fuca Ridge, and various vents between $11^{\circ} \mathrm{N}$ and $21^{\circ} \mathrm{N}$ on the EPR (Table 8.1; Spivack and Edmond 1987; Palmer 1991; You et al. 1994; James et al. 1995). Additional data come from sediment-starved back-arc basins, including the Manus Basin, the Mariana Trough, and the North Fiji Basin (Palmer 1991; Yamaoka et al. 2015a).
Boron concentrations for the endmember hydrothermal fluids for all of these sites range from seawater-like to slightly enriched $([\mathrm{B}]=0.8$ to 2 times seawater concentration). This enrichment in boron correlates with an enrichment in the light isotope, i.e., with a decrease in the $\delta^{11} \mathrm{~B}$ values from near-seawater (as high as $+38.0 \%$ ) to values as low as $+17.8 \%$ o for the most B-rich fluids (Fig. 8.5; Table 8.1). This trend is consistent with interaction of the incoming seawater with the mafic crust and extraction of isotopically light B from the rocks at high temperatures.

Such a leaching process is also predicted from estimates of high- $T\left(300{ }^{\circ} \mathrm{C}\right)$ partition coefficients of $\mathrm{B}$ between greenschist- and amphibolite-facies minerals and hydrous fluid $\left(D_{\mathrm{B}}[\mathrm{mineral} /\right.$ fluid $\left.]\right)$, which are between 0.001 and 0.03 for quartz, albite, epidote, chlorite, talc, clinopyroxene and $\mathrm{Ca}$-amphibole, predicting high fluid mobility during fluid-rock interaction under greenschist-facies conditions (Marschall et al. 2006).

Sediment-hosted vent fluids from mid-ocean ridge systems (Guyamas Basin and Escanaba Trough) and from back-arc basins (Okinawa

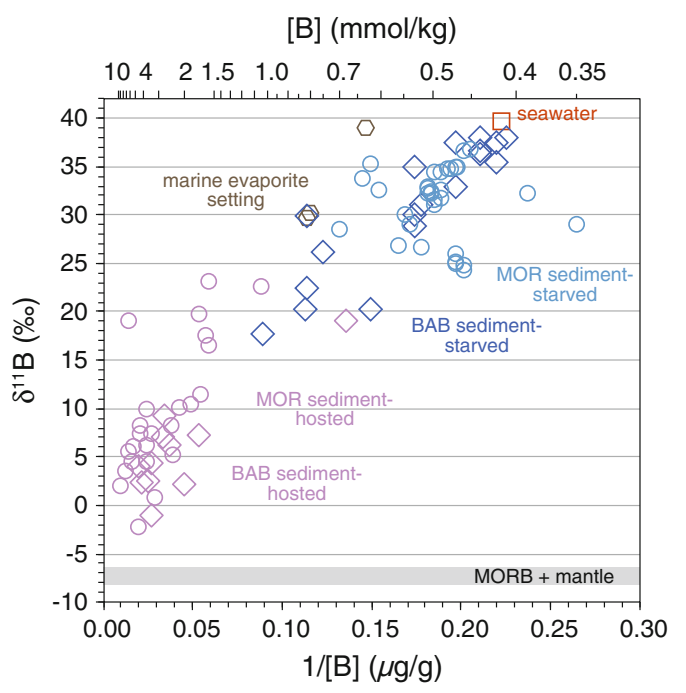

Fig. 8.5 Boron isotopic composition and B concentration of vent fluids sampled from hydrothermal vents located at mid-ocean ridges $(M O R)$ and back-arc basins $(B A B)$ with or without sediment cover on the oceanic crust. See Table 8.1 for data sources 
Trough) continue the $\mathrm{B}-\delta^{11} \mathrm{~B}$ trend observed for the sediment-starved vent fluids (Fig. 8.5). They show higher B contents than the fluids from sediment-starved systems, typically higher than $15 \mu \mathrm{g} / \mathrm{g} \quad(1.4 \mathrm{mmol} / \mathrm{kg})$ and ranging up to $105 \mu \mathrm{g} / \mathrm{g} \quad(9.7 \mathrm{mmol} / \mathrm{kg}=27$ times seawater concentration; Table 8.1). The increase in B contents is accompanied by a decrease in $\delta^{11} \mathrm{~B}$, and while some samples show values as high as $+23.2 \%$, most are below $+12 \%$, and some reach negative values as low as $-2.2 \%$ (Fig. 8.5).

Ultramafic-hosted hydrothermal systems have been sampled along the Mid-Atlantic Ridge, including boron contents from Lost City $\left(\sim 100{ }^{\circ} \mathrm{C}\right)$, Rainbow $\left(\sim 350{ }^{\circ} \mathrm{C}\right)$ and Logatchev $\left(\sim 350{ }^{\circ} \mathrm{C}\right)$. These are consistently lower than the $\mathrm{B}$ content of seawater and endmember hydrothermal fluids have been determined to $0.34-0.55 \mu \mathrm{g} / \mathrm{g} \quad(31-51 \mu \mathrm{mol} / \mathrm{kg}), \quad 2.57 \mu \mathrm{g} / \mathrm{g}$ $(238 \mu \mathrm{mol} / \mathrm{kg})$, and $3.62 \mu \mathrm{g} / \mathrm{g} \quad(335 \mu \mathrm{mol} / \mathrm{kg})$ for Lost City, Rainbow, and Logatchev, respectively (Schmidt et al. 2007; Foustoukos et al. 2008; Boschi et al. 2008; Seyfried et al. 2011, 2015). Boron isotopic data for ultramafic-hosted vent fluids are not yet available, but have been estimated to +25 to $+30 \%$ (Foustoukos et al. 2008; Boschi et al. 2008).

It is, hence, concluded from the high boron abundances in serpentinite and the lower-than-seawater abundances in ultramafichosted vent fluids that boron is sequestered from seawater during serpentinization at the seafloor. This sequestration may be strongest at lower temperatures (Lost City), but is still efficient at high temperatures (Rainbow and Logatchev). The latter contrasts with mafic systems, in which boron is leached from the rocks at high temperatures of alteration.

\subsubsection{Subaerial Hydrothermal Alteration}

Seawater contains relatively high concentrations of boron $(4.5 \mu \mathrm{g} / \mathrm{g}$ or $418 \mu \mathrm{mol} / \mathrm{kg})$ with an isotopically very heavy composition $\left(\delta^{11} \mathrm{~B}=+39.6 \%\right.$; Table 8.1$)$, which leads to the strong increase in boron abundances and $\delta^{11} \mathrm{~B}$ values of rocks altered by interaction with seawater. Meteoric waters, in contrast, have B concentrations that are typically two orders of magnitude lower than those of seawater. For example, freshwater lakes from Iceland have B contents of $23-49 \mathrm{ng} / \mathrm{g}(2.1-4.5 \mu \mathrm{mol} / \mathrm{kg})$ and $\delta^{11} \mathrm{~B}$ values between -1.8 and $+18.2 \%$ (Aggarwal et al. 2000). High-temperature hydrothermal fluids from Iceland show negative $\delta^{11} \mathrm{~B}$ values ( -6.7 to $-1.5 \%$ ) and $\mathrm{B}$ concentrations generally lower than seawater $(0.7-5.7 \mu \mathrm{g} / \mathrm{g}$; Aggarwal et al. 2000). Low-temperature well fluids show a much larger range in $\delta^{11} \mathrm{~B}$ values $(-4.7$ to $+25.0 \%$ o $)$ and lower B concentrations (0.05$1.2 \mu \mathrm{g} / \mathrm{g}$; Aggarwal et al. 2000).

Basaltic rocks from Iceland altered by meteoric fluids show elevated B contents compared to MORB (3.3-12.4 $\mu \mathrm{g} / \mathrm{g})$ and a shift to low $\delta^{11} \mathrm{~B}$ values, as low as $-18.3 \%$ (Raffone et al. 2010). This isotopically light B is also apparent in Icelandic rhyolites that were formed from or have assimilated fluid-altered crust (see above; Brounce et al. 2012). This shift towards isotopically light $\mathrm{B}$ is unique to subaerial hydrothermal alteration by meteoric water and is not observed in seawater-altered crust. Consistent with this fractionation behavior, hydrothermal fluids from subaerial systems supplied by meteoric water tend to show $\delta^{11} \mathrm{~B}$ values that are lower than the values observed in submarine hydrothermal vents (Fig. 8.5), i.e., they range from -22 to $+14 \%$ for fluids from Yellowstone, Etna, Iceland, and Alberta oil sands (Palmer and Sturchio 1990; Aggarwal et al. 2000; Pennisi et al. 2000; Williams et al. 2001b).

\subsection{Oceanic Sediments}

Oceanic sediments generally include terrigenous sediments derived from continents, dominantly delivered as detritus by wind, rivers and currents to the shelves, slopes and basins near the continents, and marine sediments including clay, biogenic carbonate and silica, which are more evenly and slowly deposited in the ocean basins. 
Pelagic clay is typically composed of smectite produced from weathering of volcanic material and illite delivered from the continents.

Pelagic clays show high B concentrations of approximately 60-160 $\mu \mathrm{g} / \mathrm{g}$ (Table 8.1; Spivack et al. 1987; Ishikawa and Nakamura 1993). Boron isotopic compositions of smectite formed by weathering of basalt at the seafloor are different from those of the terrigenous illite. Submarine smectite displays $\delta^{11} \mathrm{~B}$ values between +2 and $+9 \%$, whereas terrigenous clay shows significantly lower $\delta^{11} \mathrm{~B}$ values of -13 to $-8 \%$ (Ishikawa and Nakamura 1993). The resulting B isotopic composition of pelagic clays is a combination of these clay components in addition to biogenic carbonate and biogenic silica and ranges from -13.1 to $+5.4 \%$ o (Fig. 8.6; Table 8.1; Spivack et al. 1987; Ishikawa and Nakamura 1993; Tonarini et al. 2011). Turbidites, which are dominated by continental detritus in addition to clay derived from weathered volcanic material, also show high $\mathrm{B}$ contents and moderately negative $\delta^{11} \mathrm{~B}$ values (Fig. 8.6; Table 8.1). Marine cherts show B concentrations almost as high as turbidites and pelagic clays and a very similar range in B isotopic composition (Fig. 8.6; Table 8.1; Kolodny and Chaussidon 2004). Chemical sediments that are rich in salts and marine borates generally show high $\delta^{11} \mathrm{~B}$ that reflect their seawater origin, and concentrations may be very high, in particular in the case of borates (Swihart and Moore 1986; Vengosh et al. 1992; Paris et al. 2010).

Carbonate sediments and calcareous sediments show much lower B contents than pelagic clays, cherts and turbidites, typically $<20 \mu \mathrm{g} / \mathrm{g}$ with a wide range in isotopic composition from $\delta^{11} \mathrm{~B}=-5$ to $+26 \%$ o (Fig. 8.6; Table 8.1; Spivack and You 1997; Vengosh et al. 1991; Ishikawa and Nakamura 1993; Lécuyer et al. 2002). This variation may be related to variable amounts of clay contained in these sediments and to diagenetic processes. Pristine biogenic carbonate shows a much smaller range in isotopic composition, with $\mathrm{B}$ concentration and $\mathrm{B}$ isotopic composition depending on species, skeletal mineralogy (aragonite, calcite, or high-Mg

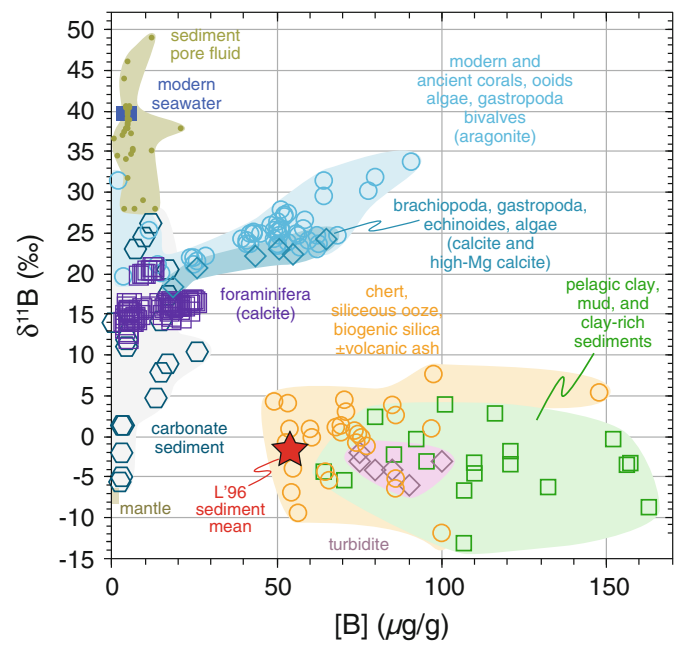

Fig. 8.6 Boron isotopic composition and B concentration of marine sediments, pore fluids, and biogenic carbonate. See Table 8.1 for data sources. The red star marks the weighted average for marine sediments proposed by Leeman and Sisson (1996)

calcite), as well as seawater $\mathrm{pH}$ and seawater $\delta^{11} \mathrm{~B}$ during growth. The details of these parameters and their impact on the $\mathrm{B}$ isotopic composition of biogenic carbonate are discussed in separate chapters of this book (Rae 2017; McCulloch et al. 2017). Concentrations of B in aragonite corals and high-Mg calcite coralline algae are generally high (typically $50 \mu \mathrm{g} / \mathrm{g}$ ), whereas foraminifera and other calcite-shell organisms show lower B contents in the range of $3-26 \mu \mathrm{g} / \mathrm{g}$ (Fig. 8.6; Table 8.1). The $\delta^{11} \mathrm{~B}$ values are typically +13 to $+20 \%$ in foraminifera and approximately $+25 \%$ in corals and coralline algae (Fig. 8.6; Table 8.1).

Boron in clay minerals is crystallographically hosted in different positions, namely adsorbed onto the mineral surface, hosted in interlayer sites of the clay, and incorporated into tetrahedral sites where it replaces $\mathrm{Si}$ or Al (Williams et al. 2001a; Williams and Hervig 2005). These different portions of B are released into pore fluids at different stages of diagenesis and metamorphism with the adsorbed B released at the earliest stage (Spivack et al. 1987). In general, recrystallization of clay minerals, and the transformation from smectite to illite during deeper burial and diagenesis is predicted to lead to fluid release 
accompanied by the preferential loss of isotopically heavy $\mathrm{B}$ and the consequential decrease in the sediment $\delta^{11} \mathrm{~B}$ with increasing grade of diagenesis (Williams et al. 2001a; Williams and Hervig 2005). Shales and slates show lower $\delta^{11} \mathrm{~B}$ values than comparable modern sediments, which is compatible with loss of isotopically heavy B during diagensis (Vengosh et al. 1991; Ishikawa and Nakamura 1993). However, in detail the exchange of boron and the fractionation of its isotopes between clay minerals and pore fluid in compacting sediments may be quite complex with various stages of adsorption and desorption, depending for example on temperature, burial depth, fluid $\mathrm{pH}$, and the concentration of ammonium released from decomposing organic matter (Hüpers et al. 2016).

During hydrothermal alteration, sediments behave similar to basaltic rocks with respect to $B$. Boron is leached from the rocks and $\delta^{11} \mathrm{~B}$ values decrease during high-temperature fluid/rock interaction. Spivack et al. (1987), for example, investigated sediments containing 32-62 $\mu \mathrm{g} / \mathrm{g}$ B with $\delta^{11} \mathrm{~B}$ values between -4.5 and $-1.2 \%$. These sediments were intruded by a basaltic sill generating hydrothermal fluid circulation within the sediments. The sediments in the vicinity of the sill showed lower B concentrations of 14$33 \mu \mathrm{g} / \mathrm{g}$, and $\delta^{11} \mathrm{~B}$ values of approximately $-8 \%$. In zones of greenschist facies hydrothermal metamorphism, B concentrations were decreased to $\sim 1.3 \mu \mathrm{g} / \mathrm{g}$ (B isotopic compositions of these B-poor samples are not reported).

A weighted average for seafloor sediments on a global scale was estimated by Leeman and Sisson (1996) to be $[\mathrm{B}]=53 \mu \mathrm{g} / \mathrm{g}$ and $\delta^{11} \mathrm{~B}=-1.6 \%$ (Fig. 8.6).

\subsection{Paleo-Ocean Chemistry of Boron}

Boron has a long residence time in the ocean of approximately 10-20 million years and is isotopically very well mixed (Lemarchand et al. 2002; Foster et al. 2010). The B isotopic composition of modern ocean water is well defined at
$+39.61 \pm 0.04 \%$ and the long residence time suggests that the rate of change was low in the Cenozoic at approximately 0.1\%o/Ma (Fig. 8.7; Lemarchand et al. 2000; Foster et al. 2010). The reconstruction of the $\mathrm{B}$ isotopic composition of ocean water is, however, a matter of debate, and especially the more distant history of its secular evolution is poorly constraint.

Accurate data on the isotopic composition of the paleo-ocean is required for reconstruction of paleo-ocean $\mathrm{pH}$, which is linked to the $\mathrm{CO}_{2}$ content of the atmosphere. The boron isotope record of biogenic carbonate is used to reconstruct the $\mathrm{pH}$ of the ocean water at the time of growth of the organism that built the carbonate shell (Rae 2017; Branson 2017; McCulloch et al. 2017). This procedure requires knowledge on the $\mathrm{pH}$-dependent $\mathrm{B}$ isotope fractionation between $\mathrm{CaCO}_{3}$ and seawater for the particular species that is investigated, but it also requires a well-defined B isotopic composition of the seawater at the time of growth.

Estimates on geochemical cycles in subduction zones and the deep mantle also require knowledge of the long-term evolution of the isotopic composition of ocean water, because strong variations in its composition would have affected the isotope budget of altered oceanic crust, serpentinites and sediments. This in turn would cause variations in the subducted and deeply recycled $\mathrm{B}$ isotope signal throughout Earth's history and would have to be taken into account in the geochemical interpretation of the rock record.

Initial work by Pearson and Palmer (2000) estimated that the $\delta^{11} \mathrm{~B}$ of seawater varied by less than 2\%o since the mid Miocene, and it was further assumed that it was close to the modern value throughout the Paleogene. More recent reconstructions of the seawater $\delta^{11} \mathrm{~B}$ value are based on box models that take into account the sources and sinks of boron in the oceans (Lemarchand et al. 2000, 2002; Joachimski et al. 2005; Simon et al. 2006). The sources are riverine input, hydrothermal vents, and fluids expelled from continental margins, while the sinks are low- $T$ alteration of the oceanic crust, 


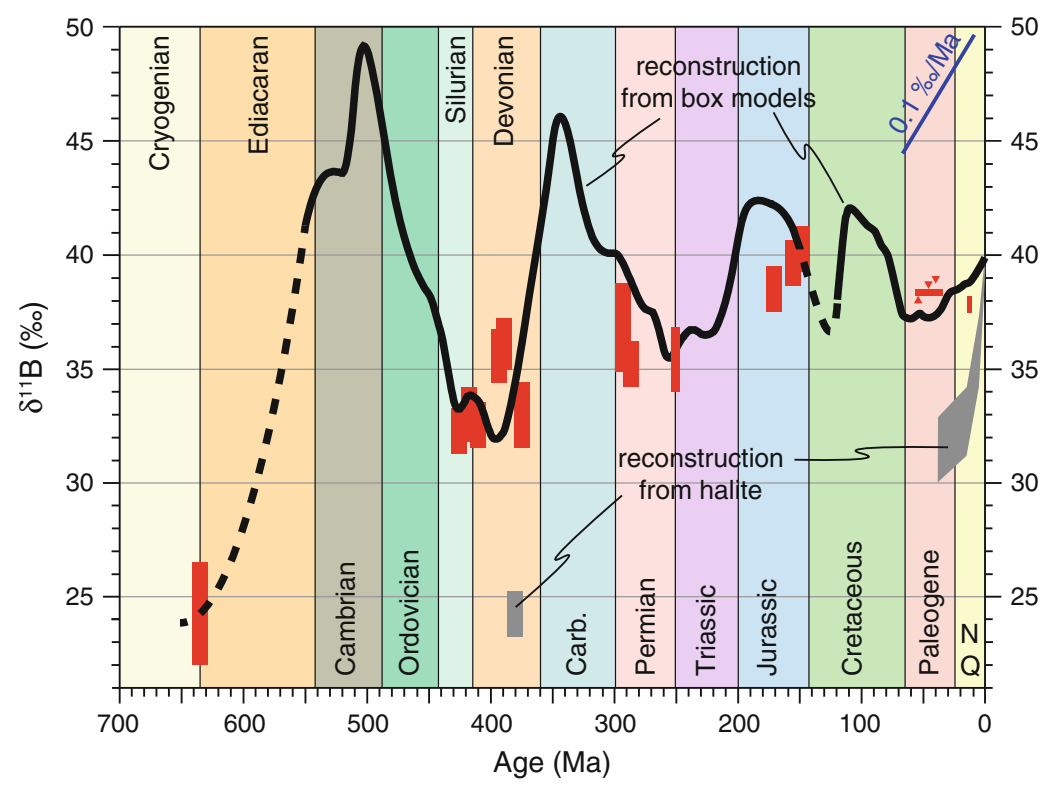

Fig. 8.7 Boron isotopic evolution of seawater during the late Neoproterozoic and Phanerozoic. Estimates marked by the thick black line are based on box models based on ocean spreading rates, major orogenies and erosion (Lemarchand et al. 2002; Joachimski et al. 2005). The stippled line is interpolated for periods where no model exists. Reconstruction of seawater $\delta^{11} \mathrm{~B}$ based on data from marine carbonate are marked in red boxes (Joachimski et al. 2005; Kasemann et al. 2010; Foster et al. 2012; Clarkson et al. 2015; Anagnostou et al. 2016). Minimum and maximum seawater values for Eocene estimates are marked by upward- and downward-pointing triangles, respectively. Reconstruction of seawater $\delta^{11} \mathrm{~B}$ based on data from halite is marked by the gray field (Paris et al. 2010). The latter is inconsistent with the carbonate reconstruction and with the box model. A more detailed discussion of the Paleogene-Neogene evolution of seawater $\delta^{11} \mathrm{~B}$ is presented by Gaillardet and Lemarchand (2017)

biogenic carbonate formed by biological species for which B isotope fractionation factors are unknown. However, several studies have used marine carbonate to reconstruct seawater $\delta^{11} \mathrm{~B}$ for various stages during the late Neoproterozoic and the Phanerozoic (Fig. 8.7; Joachimski et al. 2005; Kasemann et al. 2010; Foster et al. 2012; Clarkson et al. 2015; Anagnostou et al. 2016).

The estimates include seawater $\delta^{11} \mathrm{~B}$ variations of $\pm 2 \%$ since the Jurassic, and larger variations of $\pm 9 \%$ in the Paleozoic with excursions to very high and very low values of +32 to $+49 \%$ o (Fig. 8.7). Even more extreme values have been suggested for the end of the Cryogenian (635 Ma) with seawater $\delta^{11} \mathrm{~B}$ values as low as $+25 \%$ (Fig. 8.7; Kasemann et al. 2010).

Alternative to biogenic carbonates, halite was used to reconstruct the $\mathrm{B}$ isotopic composition of $\delta^{11} \mathrm{~B}$ of seawater complicates the interpretation of such samples, especially in the case of 
seawater. It was suggested that fluid inclusions in halite trap seawater with unfractionated B isotopes and it was demonstrated that recently formed halite faithfully reflects the $\delta^{11} \mathrm{~B}$ value of modern seawater (Paris et al. 2010). Eocene, Miocene and modern halite show an evolution of $\delta^{11} \mathrm{~B}$ values from approximately +30 to $+40 \%$, and it was concluded that the seawater value had risen by $8-10 \%$ over the past 40 million years (Fig. 8.7; Paris et al. 2010). Devonian halite suggested a seawater $\delta^{11} \mathrm{~B}$ value of approximately +25\% 380 million years ago (Fig. 8.7; Paris et al. 2010). This reconstruction of the seawater B isotopic evolution from halite is inconsistent with the box models and the carbonate record discussed above (Fig. 8.7), and it is unclear how to reconcile these contrasting records. Paris et al. (2010). suggest that the box models may have underestimated the deposition of siliciclastic material (that acts as a sink of isotopically light B) provided by the erosion of the Himalaya since the Eocene. The box models have large uncertainties, and simply varying the amount of oceanic crust that is altered along the mid-ocean ridges alone introduces a $10 \%$ uncertainty for the seawater $\delta^{11} \mathrm{~B}$ value without changing any of the other sources and sinks (Simon et al. 2006). Yet, uncertainties in the box models do not explain the discrepancies between the halite and carbonate records, and the possibility remains that the fluid inclusions trapped in ancient halite are not pristine fossil seawater, but were diagenetically processed instead.

Reconstructions of the B isotope composition of any pre-Neoproterozoic seawater that would represent the global oceans has not been completed convincingly. Attempts to do so include investigation of tourmaline from supracrustal rocks from Greenland, South Africa or Australia (Chaussidon and Albarède 1992; Chaussidon and Appel 1997; Grew et al. 2015). Tourmaline is a reliable and robust recorder of boron and other chemical and isotopic systems that will reflect the environment in which it formed (see for example reviews by van Hinsberg et al. 2011; Marschall and Jiang 2011). However, formation of this mineral from marine sediments or hydrothermal fluids is a complex process that involves multiple stages of boron enrichment and fractionation, which make it difficult to connect any tourmaline composition to the composition of seawater, even if the tourmaline-hosting sediments were initially deposited in a marine environment (Byerly and Palmer 1991; Palmer and Swihart 1996). Also, no tourmaline has ever been found in the modern marine environment, with the exception of an occurrence in a salt dome cap rock in the Gulf of Mexico (Henry et al. 1999). The seawater-tourmaline boron isotope connection proposed by Chaussidon and Appel (1997) can, therefore, not be tested with modern samples. These authors modeled the $\delta^{11} \mathrm{~B}$ value of the marine clay in which authigenic Eoarchean tourmaline from Isua (Greenland) would have formed to be $-8 \pm 7 \%$, and they argue that this requires a $\delta^{11} \mathrm{~B}$ of early Archean seawater of $+27 \pm 11 \%$. However, the estimated value for the marine clay is within the range of modern marine clay (Fig. 8.6; Table 8.1), demonstrating that the Archean clay could as well have formed in contact with seawater with a present-day B isotopic composition. The authors assumed that smectite/illite ratios were much lower in the Archean sediments, because of smaller continents and consequently a much lower input of continental detritus. Since it is really the smectite that reflects the $\mathrm{B}$ isotopic composition of the seawater and illite carries isotopically light B derived from the continents, a bulk sediment with higher smectite/illite ratio would reflect lower $\delta^{11} \mathrm{~B}$ values in the smectite and, hence, in the seawater which led to its formation (Chaussidon and Appel 1997).

In a more recent study, Grew et al. (2015) investigated a large number of tourmalines from various rock types in the Isua supracrustal belt and found a range of $\delta^{11} \mathrm{~B}$ values ranging from -29.2 to $-1.8 \%$. The authors present a box model for the evolution of $\mathrm{B}$ isotopes from seawater to clay-rich sediments followed by diagenesis and metamorphism to gneisses in which finally the tourmaline formed. This box model follows the approach of Chaussidon and Appel (1997), but results in a lower $\delta^{11} \mathrm{~B}$ estimate for 
seawater of $+14 \pm 15 \%$ based on their new sample set and modern parameters for B isotope fractionation during the various mineral-fluid fractionation steps (Grew et al. 2015). However, Grew et al. (2015) argue that this value probably does not reflect the B isotopic composition of global seawater in the early Archean, but rather the composition of water in a restricted ocean basin in which the Isua sediments were likely deposited, diagenetically altered and enriched in boron. In conclusion, the Precambrian boron isotopic evolution of seawater remains unconstrained up to the late Neoproterozoic.

\subsection{Summary and Outlook}

Boron isotopes have an important role in high-temperature geochemistry in the investigation of mantle sources of oceanic basalts, in the quantification of assimilation processes along mid-ocean ridges and on ocean islands, and in the investigation of hydrothermal alteration processes as expressed in the composition of vent fluids and altered crustal and mantle rocks, as well as sediments. The B isotopic composition of pristine, uncontaminated MORB has been determined as $\delta^{11} \mathrm{~B}=-7.1 \pm 0.9 \%$, and no variation was detected between N-MORB and E-MORB, or as a function of degree of melting or spreading rate. This value also represents the B isotopic composition of the depleted upper mantle, and probably that of the primitive mantle. Mantle-source variations for ocean island basalts detected so far show deviations of less than 5\% from the MORB value, and this spread may still be affected by crustal assimilation processes. Assimilation of seawater-altered materials or brines into magmas lead to elevated $\delta^{11} \mathrm{~B}$ values in MORB and OIB. Assimilation of crust altered by meteoric water leads to low $\delta^{11} \mathrm{~B}$ values in OIB.

The $\mathrm{B}$ concentrations and $\mathrm{B}$ isotopic variations in pristine, uncontaminated MORB and mantle samples are too low to be resolved with currently available analytical tools. Future analytical development may make these samples and their variability accessible. OIB samples already show a certain variability that is currently underexploited.

Alteration of the oceanic crust and of the exposed mantle is a major boron sink in the oceans. Low-temperature alteration and weathering of basalts lead to a strong enrichment in boron with a moderate increase in the $\delta^{11} \mathrm{~B}$ value of the rocks (Fig. 8.8). High-temperature alteration of the mafic igneous crust leads to only moderate enrichment or even leaching of boron from the rocks, but with a strongly elevated $\delta^{11} \mathrm{~B}$ value in the altered rocks (Fig. 8.8). High-temperature vent fluids are consequently enriched in boron compared to seawater, and their isotopic composition is enriched in isotopically light boron leached from the rocks (Fig. 8.8). Sediments show a very similar behavior, whereas serpentinization of mantle rocks leads to a strong enrichment of $B$ in the serpentinite even at high temperatures.

Boron isotopes also play a vital role in low-temperature geochemistry, and foremost in the reconstruction of paleo-seawater $\mathrm{pH}$ related to the evolution of the $\mathrm{CO}_{2}$ content of the atmosphere. The application of this tool hinges

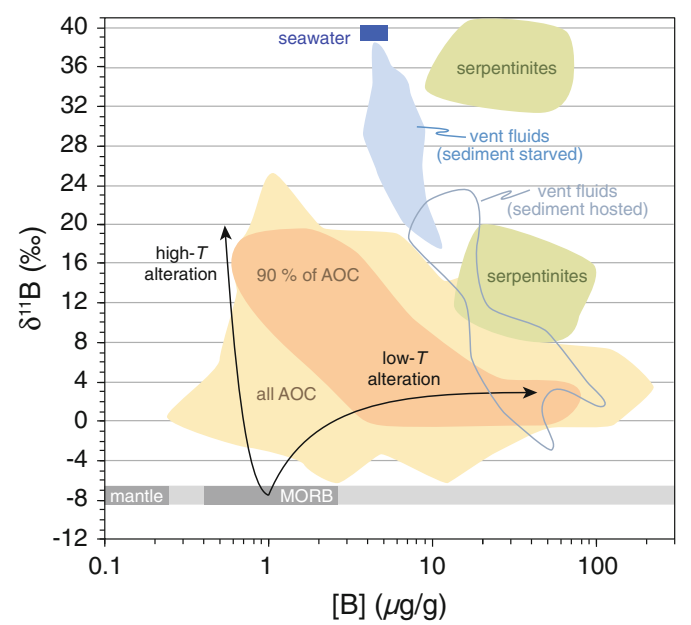

Fig. 8.8 Boron isotopic composition and B concentration of altered oceanic crust, serpentinites and vent fluids. The black arrows highlight the approximate evolution of basalts during high- $T$ and low- $T$ alteration, resepctively. Vent fluids show an evolution away from seawater towards enrichment in isotopically light B (blue field). The individual data are displayed in Figs. 8.4 and 8.5 
on the accurate knowledge of the secular evolution of the B isotopic composition of seawater, which is currently poorly constrained. Models for the evolution of seawater are afflicted with large uncertainties, and carbonate and halite records are in conflict with each other for the Phanerozoic. No reliable estimates are available for the first $85 \%$ of Earth history.

Acknowledgements I would like to thank Cees-Jan de Hoog and Angela Helbling for discussion, Simone Kasemann and Martin Palmer for constructive reviews, and Gavin Foster for editorial handling. Preparation of this review chapter was financially supported by a WHOI Independent Study Award from the Andrew W. Mellon Foundation (\#GG15920) to the author.

\section{References}

Aggarwal JK, Palmer MR, Bullen TD, Arnórsson S, Ragnarsdóttir KV (2000) The boron isotope systematics of Icelandic geothermal waters: 1. Meteoric water charged systems. Geochimica Cosmochimica Acta 64:579-585

Aggarwal J, Böhm F, Foster G, Halas S, Hönisch B, Jiang SY, Košler J, Liba A, Rodushkin I, Sheehan T, Shen JJS, Tonarini S, Xie Q, You CF, Zhao ZQ, Zuleger E (2009) How well do non-traditional stable isotope results compare between different laboratories: results from interlaboratory comparison of boron isotope measurements. J Analyt Atom Spectrom 24:825-831

Allègre CJ, Brevart O, Dupré B, Minster JF (1980) Isotopic effects produced in a continously differentiating earth mantle. Phil Trans Royal Soc 297:447-477

Allison N, Finch AA, EIMF (2010) $\delta^{11} \mathrm{~B}, \mathrm{Sr}, \mathrm{Mg}$ and B in a modern Porites coral: the relationship between calcification site $\mathrm{pH}$ and skeletal chemistry. Geochim Cosmochim Acta 74:1790-1800

Alt JC (1995) Subseafloor Processes in Mid-Ocean Ridge Hydrothermal Systems. In: Humphris SE (ed) Seafloor hydrothermal systems: physical, chemical, biological, and geological interactions, Geophysical Monograph Series, vol 91, American Geophysical Union, Washington, DC, pp 85-114

Anagnostou E, John EH, Edgar KM, Foster GL, Ridgewell A, Ingis GN, Pancost RD, Lunt DJ, Pearson PN (2016) Changing atmospheric $\mathrm{CO}_{2}$ concentration was the primary driver of early Cenozoic climate. Nature 533:380-384

Bach W, Alt JC, Niu Y, Humphris SE, Erzinger J, Dick HJB (2001) The geochemical consequences of late-stage low-grade alteration of lower ocean crust at the SW Indian Ridge: Results from ODP Hole 735B (Leg 176). Geochim Cosmochim Acta 65:3267-3287
Benton LD, Ryan JG, Tera F (2001) Boron isotope systematics of slab fluids as inferred from a serpentine seamount. Mariana forearc Earth Planet Sci Lett 187:273-282

Blamart D, Rollion-Bard C, Meibom A, Ciuf JP, Juillet-Leclerc A, Dauphin Y (2007) Correlation of boron isotopic composition with ultrastructure in the deep-sea coral Lophelia pertusa: implications for biomineralization and paleo-pH. Geochem Geophys Geosys $\left(\mathrm{G}^{3}\right)$ 8, Q12001

Boschi C, Dini A, Früh-Green GL, Kelley DS (2008) Isotopic and element exchange during serpentinization and metasomatism at the Atlantis Massif (MAR $30^{\circ}$ $\mathrm{N}$ ): insights from $\mathrm{B}$ and $\mathrm{Sr}$ isotope data. Geochim Cosmochim Acta 72:1801-1823

Branson O (2017) Boron incorporation into marine $\mathrm{CaCO}_{3}$. In: Marschall HR, Foster GL (eds) Boron Isotopes-The Fifth Element, Advances in Isotope Geochemistry, vol 7. Springer, Heidelberg, 71-105

Brounce M, Feineman MD, LaFemina P, Gurenko AA (2012) Insights into crustal assimilation by Icelandic basalts from boron isotopes in melt inclusions from the 1783-1784 Lakaggar eruption. Geochim Cosmochim Acta 94:164-180

Byerly GR, Palmer MR (1991) Tourmaline mineralization in the Barberton greenstone belt, South Africa: early Archean metasomatism by evaporite-derived boron. Contrib Mineral Petrol 107:387-402

Chase CG (1981) Oceanic island $\mathrm{Pb}$-2-stage histories and mantle evoltuion. Earth Planet Sci Lett 52:277284

Chaussidon M, Albarède F (1992) Secular boron isotope variations in the continental crust: an ion microprobe study. Earth Planet Sci Lett 108:229-241

Chaussidon M, Appel PWU (1997) Boron isotopic composition of tourmalines from the 3.8-Ga-old Isua supracrustals, West Greenland: implications on the $\delta^{11} \mathrm{~B}$ value of early Archean seawater. Chem Geol 136:171-180

Chaussidon M, Jambon A (1994) Boron content and isotopic composition of oceanic basalts: geochemical and cosmochemical implications. Earth Planet Sci Lett 121:277-291

Chaussidon M, Marty B (1995) Primitive boron isotope composition of the mantle. Science 269:383-386

Chavagnac V, Monnin C, Ceuleneer G, Boulart C, Hoareau G (2013) Characterization of hyperalkaline fluids produced by low-temperature serpentinization of mantle peridotites in the Oman and Ligurian ophiolites. Geochem Geophys Geosys G3(14):24962522

Clarkson MO, Kasemann SA, Wood RA, Lenton TM, Daines SJ, Richoz S, Ohnemueller F, Meixner A, Poulton SW, Tipper ET (2015) Ocean acidification and the Permo-Triassic mass extinction. Science 348:229-232

Collerson KD, Williams Q, Ewart AE, Murphy DT (2010) Origin of HIMU and EM-1 domains sampled by ocean island basalts, kimberlites and carbonatites: the role of $\mathrm{CO}_{2}$-fluxed lower mantle melting in 
thermochemical upwellings. Phys Earth Planet Inter 181:112-131

De Hoog CJ, Savov IP (2017) Subduction zones, dehydration, metasomatism, mud and serpentinite volcanoes, and arc magmatism. In: Marschall HR, Foster GL (eds) Boron isotopes-The fifth element, Advances in Isotope Geochemistry, vol 7, Springer, Heidelberg, 219-249

Dhuime B, Hawkesworth CJ, Cawood PA, Storey CD (2012) A change in the geodynamics of continental growth 3 billion years ago. Science 335:1334-1336

Dick HJB, Jian L, Schouten H (2003) An ultraslow-spreading class of ocean ridge. Nature 426:405-412

Dilek Y (2003) Ophiolite concept and its evolution. In: Dilek Y, Newcomb S (eds) Ophiolite concept and the evolution of geological thought, Special Paper Geological Society of America, vol 373. Boulder, Colorado, pp 1-16

Donnelly T, Francheteau J, Bryan W, Robinson P, Flower M, Salisbury M (eds) (1979) The chemistry of altered basalts at site 417, Deep Sea Drilling Project Leg 51, Initial Reports of the Deep Sea Drilling Project, vol. 51-53, U.S. Government Printing Office, Washington, D.C

Elliott T, Plank T, Zindler A, White W, Bourdon B (1997) Element transport from slab to vocanic front at the Mariana arc. J Geophys Res 102:14991-15019

Escartn J, Smith DK, Cann J, Schouten H, Langmuir CH, Escrig S (2008) Central role of detachment faults in accretion of slow spread oceanic lithosphere. Nature 455:790-794

Fietzke J, Ragazzola F, Halfar J, Dietze H, Foster LC, Hansteen TH, Eisenhauer A, Steneck RS (2015) Century-scale trends and seasonality in $\mathrm{pH}$ and temperature for shallow zones of the Bering Sea. Proc Nat Acad Sci 112:2960-2965

Fonseca ROC, Kirchenbaur M, Ballhaus C, Münker C, Zirner A, Gerdes A, Heuser A, Botcharnikov R, Lenting C (2017) Fingerprinting fuid sources in Troodos ophiolite complex orbicular glasses using high spatial resolution isotope and trace element geochemistry. Geochim Cosmochim Acta 200:145-166

Foster GL (2008) Seawater $\mathrm{pH}, p \mathrm{CO}_{2}$ and $\left[\mathrm{CO}_{3}^{2-}\right]$ variations in the Caribbean Sea over the last 130kyr: a boron isotope and $\mathrm{B} / \mathrm{Ca}$ study of planktic for aminifera. Earth Planet Sci Lett 271:254-266

Foster GL, Pogge von Strandmann PAE, Rae JWB (2010) Boron and magnesium isotopic composition of seawater. Geochem Geophys Geosys $\left(\mathrm{G}^{3}\right) 11$, Q08015

Foster GL, Lear CH, Rae JWB (2012) The evolution of $p \mathrm{CO}_{2}$, ice volume and climate during the middle Miocene. Earth Planet Sci Lett 341-344:243-254

Foster GL, Hönisch B, Paris G, Dwyer GS, Rae JWB, Elliott T, Gaillardet J, Hemming NG, Louvat P, Vengosh A (2013) Interlaboratory comparison of boron isotope analyses of boric acid, seawater and marine $\mathrm{CaCO}_{3}$ by MC-ICPMS and NTIMS. Chem Geol 358:1-14
Foster GL, Marschall HR, Palmer MR (2017) Boron isotope analysis of geologic materials. In: Marschall HR, Foster GL (eds) Boron Isotopes-The Fifth Element, Advances in Isotope Geochemistry, vol. 7, Springer, Heidelberg, 13-31

Foustoukos DI, Savov IP, Janecky DR (2008) Chemical and isotopic constraints on water/rock interactions at the Lost City hydrothermal field, $30 \mathrm{~N}$ Mid-Atlantic Ridge. Geochim Cosmochim Acta 72:5457-5474

Gaillardet J, Allegre CJ (1995) Boron isotopic compositions of corals: seawater or diagenesis record? Earth Planet. Sci Lett 136:665-676

Gaillardet J, Lemarchand D (2017) Boron isotopes in riverine systems and the weathering environment. In: Marschall HR, Foster GL (eds) Boron Isotopes-The Fifth Element, Advances in Isotope Geochemistry, vol. 7, Springer, Heidelberg, 165-190

Gannoun A, Burton KW, Parkinson IJ, Alard O, Schiano P, Thomas LE (2007) The scale and origin of the osmium isotope variations in mid-ocean ridge basalts. Earth Planet Sci Lett 259:541-556

Genske FS, Turner SP, Beier C, Chu MF, Tonarini S, Pearson NJ, Haase KM (2014) Lithium and boron isotope systematics in lavas from the Azores islands reveal crustal assimilation. Chem Geol 373:27-36

German CR, Lin J (2004) The thermal structure of the oceanic crust, ridge spreading and hydrothermal circulation: how well do we understand their interconnections? In: German CR, Lin J, Parson LM (eds) Mid-Ocean ridges: hydrothermal interactions between the lithosphere and Oceans, Geophysical Monograph Series, vol 148, American Geophysical Union, pp 1-18

Grew ES, Dymek RF, de Hoog CJ, Harley SL, Boak J, Hazen RM, Yates MG (2015) Boron isotopes in tourmaline from the ca. 3.7-3.8 a Isua supracrustal belt, Greenland: sources for boron in Eoarchean continental crust and seawater. Geochim Cosmochim Acta 163:156-177

Gurenko AA, Chaussidon M (1997) Boron concentrations and isotopic composition of the Icelandic mantle: evidence from glass inclusions in olivine. Chem Geol 135:21-34

Gurenko AA, Kamenetsky VS (2011) Boron isotopic composition of olivine-hosted melt inclusions from Gorgona komatiites, Colombia: new evidence supporting wet komatiite origin. Earth Planet Sci Lett 312:201-212

Halliday AN, Davidson JP, Holden P, Dewolf C, Lee DC, Fitton JG (1990) Trace- Element fractionation in plumes and the origin of HIMU mantle beneath the Cameroon Line. Nature 347:523-528

Hart SR, Blusztajn J, Dick HJB, Meyer PS, Muehlenbachs K (1999) The fingerprint of seawater circulation in a 500-meter section of ocean crust gabbros. Geochim Cosmochim Acta 63:4059-4080

Harvey J, Savov IP, Agostini S, Cliff RA, Walshaw R (2014) Si-metasomatism in serpentinized peridotite: the effects of talc-alteration on strontium and boron 
isotopes in abyssal serpentinites from Hole 1268a, ODP Leg 209. Geochim Cosmochim Acta 126:30-48

Hemming NG, Hanson GN (1992) Boron isotopic composition and concentration in modern marine carbonates. Geochim Cosmochim Acta 56:537-543

Hemming NG, Guilderson TP, Fairbanks RG (1998) Seasonal variations in the boron isotopic composition of coral: a productivity signal? Global Biogeochem. Cycles 12:581-586

Henry DJ, Kirkland BL, Kirkland DW (1999) Sector-zoned tourmaline from the cap rock salt dome. Eur J Mineral 11:263-280

Hofmann AW (1988) Chemical differentiation of the Earth: the relationship between mantle, continental crust, and oceanic crust. Earth Planet Sci Lett 90:297314

Hofmann AW (1997) Mantle geochemistry: the message from oceanic volcanism. Nature 385:219-229

Hofmann AW (2003) Sampling mantle heterogeneity through oceanic basalts: isotopes and trace elements. In: Holland HD, Turekian KK (eds) The mantle and core, Treatise on Geochemistry, vol 2, Elsevier-Pergamon, pp 61-101

Hofmann AW, White WM (1982) Mantle plumes from ancient oceanic crust. Earth Planet Sci Lett 57:421436

Hüpers A, Kasemann SA, Kopf AJ, Meixner A, Toki T, Shinjo R, Wheat CG, You CF (2016) Fluid flow and water-rock interaction across the active Nankai Trough subduction zone forearc revealed by boron isotope geochemistry. Geochim Cosmochim Acta 193:100-118

Ishikawa T, Nakamura E (1992) Boron isotope geochemistry of the oceanic crust from DSDP/ODP Hole 504B. Geochim Cosmochim Acta 56:1633-1639

Ishikawa T, Nakamura E (1993) Boron isotope systematics of marine sediments. Earth Planet Sci Lett 117:567-580

Jackson MG, Hart SR, Koppers AAP, Staudigel H, Konter J, Blusztajn J, Kurz M, Russel JA (2007) The return of subducted continental crust in Samoan lavas. Nature 448:684-687

James RH, Palmer MR (2000) Marine geochemical cycles of the alkali elements and boron: the role of sediments. Geochim Cosmochim Acta 64:3111-3122

James RH, Elderfield H, Palmer MR (1995) The chemistry of hydrothermal fluids from Broken Spur site, 29 N Mid-Atlantic Ridge. Geochim Cosmochim Acta 59:651-659

James RH, Rudnicki MD, Palmer MR (1999) The alkali element and boron geochemistry of the Escanaba Trough sediment-hosted hydrothermal system. Earth Planet Sci Lett 171:157-169

Joachimski MM, Simon L, van Geldern R, Lécuyer C (2005) Boron isotope geochemistry of Paleozoic brachiopod calcite: implications for a seular change in the boron isotope geochemistry of seawater over the Phanerozoic. Geochim Cosmochim Acta 69:40354044
Jochum KP, Stoll B, Herwig K, Willbold M, Hofmann A, Amini M, Aarburg S, Abouchami W, Hellebrand E, Mocek B, Raczek I, Stracke A, Alard O, Bouman C, Becker S, Dücking M, Brätz H, Klemd R, de Bruin D, Canil D, Cornell D, de Hoog CJ, Dalpé C, Danyushevsky LV, Eisenhauer A, Gao Y, Snow JE, Groschopf N, Günther D, Latkoczy C, Giullong M, Hauri EH, Höfer HE, Lahaye Y, Horz K, Jacob DE, Kasemann SA, Kent AJR, Ludwig T, Zack T, Mason PRD, Meixner A, Rosner M, Misawa K, Nash BP, Pfänder JA, Premo WR, Sun WD, Tiepolo M, Vannucci R, Vennemann T, Wayne D, Woodhead JD (2006) MPI-DING reference glasses for in situ microanalysis: New reference values for element concentrations and isotope ratios. Geochem Geophys Geosys $\left(\mathrm{G}^{3}\right)$ 7, Q02008. doi:10.1029/ 2005GC001060

Karson JA, Kelley DS, Fornari DJ, Perfit MR, Shank TM (2015) Discovering the deep: a photographic atlas of the seafloor and oceanic crust. Cambridge University Press

Kasemann S, Erzinger J, Franz G (2000) Boron recycling in the continental crust of the central Andes from the Paleozoic to Mesozoic, NW Argentina. Contrib Mineral Petrol 140:328-343

Kasemann SA, Prave AR, Fallick AE, Hawkesworth CJ, Hoffmann KH (2010) Neoproterozoic ice ages, boron isotopes, and ocean acidification: implications for a snowball Earth. Geology 38:775-778

Kobayashi K, Tanaka R, Moriguti T, Shimizu K, Nakamura E (2004) Lithium, boron, and lead isotope systematics of glass inclusions in olivines from Hawaiian lavas: evidence for recycled components in the Hawaiian plume. Chem Geol 212:143-161

Kolodny Y, Chaussidon M (2004) Boron isotopes in DSDP cherts: fractionation and diagenesis. In: Hill RJ, Leventhal J, Aizenshtat Z, Baedecker MJ, Claypool G (eds) Geochemical investigations in earth and space science: a tribute to Isaac R. Kaplan, vol 9, The Geochemical Society Special Publications, pp 1-14

Kopf A, Deyhle A (2002) Back to the roots; boron geochemistry of mud volcanoes and its implications for mobilization depth and global B cycling. Chem Geol 192:195-210

Kopf A, Deyhle A, Zuleger E (2000) Evidence for deep fluid circulation and gas hydrate dissociation using boron and boron isotopes of pore fluids in forearc sediments from Costa Rica (ODP Leg 170). Marine Geol 167:1-28

Kopf A, Germán M, Deyhle A, Frape S, Hesse R (2003) Fluid geochemistry in the Japan trench forearc (ODP Leg 186): a synthesis. Proc Ocean Drill Progr Sci Res 186:1-23

Kowalski P, Wunder B (2017) Boron-isotope fractionation among solids-fluids-melts: experiments and atomic modeling. In: Marschall HR, Foster GL (eds) Boron Isotopes-The Fifth Element, Advances in Isotope Geochemistry, vol 7, Springer, Heidelberg, 33-69 
Lécuyer C, Grandjean $\mathrm{P}$, Reynard $\mathrm{B}$, Albarède $\mathrm{F}$, Telouk P (2002) ${ }^{11} \mathrm{~B} /{ }^{10} \mathrm{~B}$ analysis of geological materials by ICP-MS Plasma 54: application to the boron fractionation between brachiopod calcite and seawater. Chem Geol 186:45-55

Leeman WP, Sisson VB (1996) Geochemistry of boron and its implications for crustal and mantle processes. In: Grew ES, Anovitz LM (eds) Boron: mineralogy, petrology and geochemistry, Reviews in mineralogy, vol 33, pp 645-695

Lemarchand D, Gaillardet J, Lewin É, Allègre CJ (2000) The influence of rivers on marine boron isotopes and implications for reconstructing past ocean $\mathrm{pH}$. Nature 408:951-954

Lemarchand D, Gaillardet J, Lewin É, Allègre CJ (2002) Boron isotope systematics in large rivers: implications for the marine boron budget and paleo-pH reconstruction over the Cenozoic. Chem Geol 190:123-140

le Roux PJ, Shirey SB, Benton L, Hauri EH, Mock TD (2004) In situ, multiple-multiplier, laser ablation ICP-MS measurement of boron isotopic composition $(\delta 11 \mathrm{~B})$ at the nanogram level. Chem Geol 203:123138

Marschall HR (2017) Boron isotopes in the ocean floor realm and the mantle. In: Marschall HR, Foster GL (eds) Boron Isotopes-The Fifth Element, Advances in Isotope Geochemistry, vol 7, Springer, Heidelberg, 191-217

Marschall HR, Jiang SY (2011) Tourmaline isotopes: no element left behind. Elements 7:313-319

Marschall HR, Monteleone BD (2015) Boron isotope analysis of silicate glass with very-low boron concentrations by secondary-ion mass spectrometry. Geostand Geoanal Res 39:31-46

Marschall HR, Schumacher JC (2012) Arc magmas sourced from mélange diapirs in subduction zones. Nature Geosci 5. 10.1038/NGEO1634

Marschall HR, Altherr R, Ludwig T, Kalt A, Gméling K, Kasztovszky Z (2006) Partitioning and budget of Li, $\mathrm{Be}$ and $\mathrm{B}$ in high-pressure metamorphic rocks. Geochim Cosmochim Acta 70:4750-4769

Marschall HR, Wanless VD, Shimizu N, Pogge von Strandmann PAE, Elliott T, Monteleone BD (2017) The boron and lithium isotopic composition of mid-ocean ridge basalts and the mantle. Geochim Cosmochim Acta, Geochim 207:102-138. doi:10. 1016/j.gca.2017.03.028

McCulloch MT, D’Olivio JP, Falter J, Georgiou L, Holcomb M, Montagna P, Trotter J (2017) Boron isotopes in corals. In: Marschall HR, Foster GL (eds) Boron Isotopes-The Fifth Element, Advances in Isotope Geochemistry, vol 7, Springer, Heidelberg, 145-163

McKenzie D, O’Nions RK (1983) Mantle reservoirs and ocean island basalts. Nature 301:229-231

Menzies MA, Wass SY (1983) $\mathrm{CO}_{2}$-rich and LREE-rich mantle below eastern Australia-a REE and isotopic study of alkaline magmas and apatite-rich mantle xenoliths from the Southern-Highlands province. Australia Earth Planet Sci Lett 65:287-302
Moriguti T, Nakamura E (1998) Across-arc variation of $\mathrm{Li}$-isotopes in lavas and implications for crust/mantle recycling at subduction zones. Earth Planet Sci Lett 163:167-174

Müller RD, Sdrolias M, Gaina C, Roest WR (2008) Age, spreading rates, and spreading asymmetry of the world's ocean crust. Geochem Geophys Geosys $\left(\mathrm{G}^{3}\right)$ 9, Q04006

Nebel O, Arculus RJ, van Westrenen W, Woodhead JD, Jenner FE, Nebel-Jacobsen YJ, Wille M, Eggins SM (2013) Coupled $\mathrm{Hf}-\mathrm{Nd}-\mathrm{Pb}$ isotope co-variation of HIMU oceanic island basalts from Mangaia, Cook-Austral islands, suggest an Archean source component in the mantle transition zone. Geochim Cosmochim Acta 112:87-101

O'Neill HSC, Jenner FE (2012) The global pattern or trace-element distributions in ocean floor basalts. Nature 491:698-704

Palmer MR (1991) Boron isotope systematics of hydrothermal fluids and tourmalines: a synthesis. Chem Geol 94:111-121

Palmer MR, Sturchio NC (1990) The boron isotope systematics of the Yellowstone National Park (Wyoming) hydrothermal system: a reconnaissance. Geochim Cosmochim Acta 54:2811-2815

Palmer MR, Swihart GH (1996) Boron isotope geochemistry: an overview. In: Grew ES, Anovitz LM (eds) Boron: mineralogy, petrology and geochemistry, Reviews in Mineralogy, 1st edn. vol 33, Mineralogical Society of America, Washington, DC, pp 709-740

Palmer MR, Spivack AJ, Edmond JM (1987) Temperature and $\mathrm{pH}$ controls over isotopic fractionation during adsorption of boron on marine clay. Geochim Cosmochim Acta 51:2319-2323

Paris G, Gaillardet J, Louvat P (2010) Geological evolution of seawater boron isotopic composition recorded in evaporites. Geology 38:1035-1038

Pearson PN, Palmer MR (2000) Atmospheric carbon dioxide concentrations over the past 60 million years. Nature 406:695-699

Pennisi M, Leeman WP, Tonarini S, Pennisi A, Nabelek P (2000) Boron, Sr, O, and $\mathrm{H}$ isotope geochemistry of groundwaters from Mt. Etna (Sicily)-hydrologic implications. Geochim Cosmochim Acta 64:961-974

Rae JWB (2017) Boron isotopes in foraminfera. In: Marschall HR, Foster GL (eds) Boron Isotopes-The Fifth Element, Advances in Isotope Geochemistry, vol 7, Springer, Heidelberg, 107-143

Rae JWB, Foster GL, Schmidt DN, Elliott T (2011) Boron isotopes and $\mathrm{BCa}$ in benthic foraminifera: proxies for the deep ocean carbonate system. Earth Planet Sci Lett 302:403-413

Raffone N, Ottolini LP, Tonarini S, Gianelli G, D’Orazio M, Friedleifsson GO (2010) An investigation of trace and isotope light elements in mineral phases from well RN-17 (Reykjanes Peninsula, SW Iceland). In: 11th European Workshop on Modern Developments and Applications in Microbeam Analysis, IOP Conference Series: Materials Science and Engineering, vol 7, IOP Publishing, 012026 
Reymer A, Schubert G (1984) Phanerozoic addition rates to the continental crust and crustal growth. Tectonics 3:63-77

Reynolds JR, Langmuir CH, Bender JF, Kastens KA, Ryan WBF (1992) Spatial and temporal variability in the geochemistry of basalts from the East Pacific Rise. Nature 359:493-499

Rose-Koga EF, Sigmarsson O (2008) B-O-Th isotope systematics in Icelandic tephra. Chem Geol 255:454 462

Roy-Barman M, Wasserburg GJ, Papanastassiou DA, Chaussidon M (1998) Osmium isotopic compositions and $\mathrm{Re}-\mathrm{Os}$ concentrations in sulfide globules from basaltic glasses. Earth Planet Sci Lett 154:331-347

Ryan JG, Langmuir CH (1993) The systematics of boron abundances in young volcanic rocks. Geochim Cosmochim Acta 57:1489-1498

Schmidt K, Koschinsky A, Garbe-Schönberg D, de Carvalho LM, Seifert R (2007) Geochemistry of hydrothermal fluids from the ultramafic-hosted Logatchev hydrothermal field, $15 \mathrm{~N}$ on the Mid-Atlantic Ridge: temporal and spatial investigation. Chem Geol 242:1-21

Schwarcz HP, Agyei EK, McMullen CC (1969) Boron isotopic fractionation during clay adsorption from sea-water. Earth Planet Sci Lett 6:1-5

Searle M, Cox J (1999) Tectonic setting, origin, and obduction of the Oman ophiolite. Geol Soc Am Bull 111:104-122

Seyfried WE Jr, Pester NJ, Ding K, Rough M (2011) Vent fluid chemistry of the Rainbow hydrothermal system (36 N, MAR): phase equilibria and in situ pH controls on subseafloor alteration processes. Geochim Cosmochim Acta 75:1574-1593

Seyfried WE Jr, Pester NJ, Tutolo B, Ding K (2015) The Lost City hydrothermal system: constraints imposed by vent fluid chemistry and reaction path models on subseafloor heat and mass transfer processes. Geochim Cosmochim Acta 163:59-79

Shaw AM, Hauri EH, Behn MD, Hilton DR, Macpherson CG, Sinton JM (2012) Long-term preservation of slab signatures in the mantle inferred from hydrogen isotopes. Nat Geosci 5:224-228

Simon L, Lécuyer C, Maréchal C, Coltice N (2006) Modelling the geochemical cycle of boron: implications for the long-term $\delta^{11} \mathrm{~B}$ evolution of seawater and oceanic crust. Chem Geol 225:61-76

Smith HJ, Spivack AJ, Staudigel H, Hart SR (1995) The boron isotopic composition of altered oceanic crust. Chem Geol 126:119-135

Spivack AJ, Edmond JM (1987) Boron isotope exchange between seawater and the oceanic crust. Geochim Cosmochim Acta 51:1033-1043

Spivack AJ, You CF (1997) Boron isotopic geochemistry of carbonates and pore waters, Ocean Drilling Program Site 851. Earth Planet Sci Lett 152:113-122

Spivack AJ, Palmer MR, Edmond JM (1987) The sedimentary cycle of the boron isotopes. Geochim Cosmochim Acta 51:1939-1949
Stracke A, Hofmann AW, Hart SR (2005) Fozo, HIMU, and the rest of the mantle zoo. Geochem Geophys Geosys $\left(\mathrm{G}^{3}\right)$ 6, Q05007

Sun SS, Nesbitt RW, Sharaskin AY (1979) Geochemical characteristics of mid-ocean ridge basalts. Earth Planet Sci Lett 44:119-138

Swihart GH, Moore PB (1986) Boron isotopic composition of marine and nonmarine evaporite borates. Geochim Cosmochim Acta 50:1297-1301

Tanaka R, Nakamura E (2005) Boron isotopic constraints on the source of Hawai'ian shield lavas. Geochim Cosmochim Acta 69:3385-3399

Thompson G, Melson WG (1970) Boron contents of serpentinites and metabasalts in the oceanic crust: implicatons for the boron cycle in the oceans. Earth Planet Sci Lett 8:61-65

Tonarini S, Leeman WP, Leat PT (2011) Subduction erosion of forearc mantle wedge implicated in the genesis of the South Sandwich Island (SSI) arc: evidence from boron isotope systematics. Earth Planet Sci Lett 301:275-284

Turner S, Tonarini S, Bindemann I, Leeman WP, Schaefer BF (2007) Boron and oxygen isotope evidence for recycling of subducted components over the past 2.5 Gyr. Nature 447:702-705

Uppstroem LR (1974) The boron/chlorinity ratio of deep seawater from the Pacific Ocean. Deep Sea Res 21:161-162

van Hinsberg VJ, Henry DJ, Marschall HR (2011) Tourmaline: an ideal indicator of its host environment. Can Mineral 49:1-16

van Keken PE, Hauri EH, Ballentine CJ (2002) Mantle mixing: the generation, preservation, and destruction of chemical heterogeneity. Ann Rev Earth Planet Sci 30:493-525

Vengosh A, Kolodny Y, Starinsky A, Chivas AR, McCulloch MT (1991) Coprecipitation and isotopic fractionation of boron in modern biogenic carbonates. Geochim Cosmochim Acta 55:2901-2910

Vengosh A, Starinsky A, Kolodny Y, Chivas AR, Raab M (1992) Boron variations during fractional evaporation of seawater: new constraints on the marine vs nonmarine debate. Geology 20:799-802

Vidal P, Dosso L (1978) Core formation-catastrophic or continuous - $\mathrm{Sr}$ and $\mathrm{Pb}$ isotope geochemistry constraints. Geophys Res Lett 5:169-172

Vils F, Tonarini S, Kalt A, Seitz HM (2009) Boron, lithium and strontium isotopes as tracers of seawaterserpentinite interaction at Mid-Atlantic ridge, ODP Leg 209. Earth Planet Sci Lett 286:414-425

Weaver BL (1991) The origin of ocean island basalt end-member compositions-trace-element and isotopic constraints. Earth Planet Sci Lett 104:381-397

Williams LB, Hervig RL (2005) Lithium and boron isotopes in illite-smectite: the importance of crystal size. Geochim Cosmochim Acta 69:5705-5716

Williams LB, Hervig RL, Holloway JR, Hutcheon I (2001a) a B isotope geochemistry during diagenesis. Part I. Experimental determination of fractionation 
during illitization of smectite. Geochim Cosmochim Acta 65:1769-1782

Williams LB, Wieser ME, Fennell J, Hutcheon I, Hervig RL (2001b) b Application of boron isotopes to the understanding of fluid-rock interactions in a hydrothermally stimulated oil reservoir in the Alberta Basin. Can Geofl 1:229-240

Yamaoka K, Ishikawa T, Matsubaya O, Ishiyama D, Nagaishi K, Hiroyasu Y, Chiba H, Kawahata H (2012) Boron and oxygen isotope systematics for a complete section of oceanic crustal rocks in the Oman ophiolite. Geochim Cosmochim Acta 84:543-559

Yamaoka K, Hong E, Ishikawa T, Gamo T, Kawahata H (2015a) a Boron isotope geochemistry of vent fluids from arc/back-arc seafloor hydrothermal systems in the western Pacific. Chem Geol 392:9-18

Yamaoka K, Matsukura S, Ishikawa T, Kawahata H (2015b) b Boron isotope systematics of a fossil hydrothermal system from the Troodos ophiolite,
Cyprus: water-rock interactions in the oceanic crust and subseafloor ore deposits. Chem Geol 396:61-73

You CF, Spivack AJ, Smith JH, Gieskes JM (1993) Mobilization of boron in convergent margins: implications for the boron geochemical cycle. Geology 21:207-210

You CF, Butterfield DA, Spivack AJ, Gieskes JM, Gamo T, Campbell AJ (1994) Boron and halide systematics in submarine hydrothermal systems: effects of phase separation and sedimentary contributions. Earth Planet. Sci. Lett. 123:227-238

You CF, Chan LH, Spivack AJ, Gieskes JM (1995) Lithium, boron, and their isotopes in sediments and pore waters of Ocean Drilling Program Site 808, Nankai Trough: implications for fluid expulsion in accretionary prisms. Geology 23:37-40

Zindler A, Hart SR (1986) Chemical geodynamics. Ann Rev Earth Planet Sci 14:493-571
Open Access This chapter is licensed under the terms of the Creative Commons Attribution 4.0 International License (http://creativecommons.org/licenses/by/4.0/), which permits use, sharing, adaptation, distribution and reproduction in any medium or format, as long as you give appropriate credit to the original author(s) and the source, provide a link to the Creative Commons license and indicate if changes were made.
The images or other third party material in this chapter are included in the chapter's Creative Commons license, unless indicated otherwise in a credit line to the material. If material is not included in the chapter's Creative Commons license and your intended use is not permitted by statutory regulation or exceeds the permitted use, you will need to obtain permission directly from the copyright holder. 